Çukurova Üniversitesi İlahiyat Fakültesi Dergisi

Y11: 2020 Cilt: 20 Sayı: 2 e-ISSN 2564-6427

Dergi Web Sayfası: http://dergipark.gov.tr/cuilah

\title{
YEMEN ARAPÇASINDA TÜRKÇE UNSURLAR
}

\author{
Turkish Elements in Yemeni Arabic
}

\section{Ertuğrul DÖNER' Yusuf ÖZCAN ${ }^{2}$}

\begin{tabular}{cc}
\multicolumn{2}{c}{ Makale Bilgileri } \\
\hline Geliş Tarihi: & 15.10 .2020 \\
Kabul Tarihi: & 16.11 .2020 \\
Yayın Tarihi: & 25.12 .2020
\end{tabular}

\begin{abstract}
Özet
Önemli birtakım deniz yolları üzerinde bulunan ve bereketli topraklara sahip olan Yemen farklı kültür ve medeniyetlerin uğrak mekanı olmuş, birçok devlete ev sahipliği yapmış, jeoplolitik konumu itibariyle de her daim önemini korumuştur. Bu bölgeye özellikle 16. yüzyıldan itibaren Osmanlı Devleti dahil olmuş, Osmanlı'nın Yemen hakimiyeti kesintilerle birlikte 20. yüzyılın başlarına kadar devam etmiştir. Osmanlı Devleti zamanında bölgede çıkan birçok isyan ve sıkıntılara rağmen siyasi, idari, dini ve içtimai alanlarda yapılar inşa edilmiş, farklı kültürlerin içiçe yaşadığı Yemen'de Osmanlı kültürü varlık alanı bulmuştur. Bu varlık alanlarından biri de kültürlerin etkileşim aracı olan dildir. Bu çalışmada Yemen-Osmanlı münasebetleri çerçevesinde Yemen Arap lehçesinde kullanılan Türkçe unsurların belirlenmesi ve çeşitli yönleriyle değerlendirilmesi hedeflenmiştir. Aslında Türkçe-Arapça etkileşimi genel olarak Türklerin İslamiyeti kabulü neticesinde ilk olarak dinî lafizların aktarımıyla başlayan ve zamanla gündelik konuşma diline varıncaya kadar hayatın diğer alanlarında da etkisini hissettiren doğal bir süreç olarak karşımıza çıkmaktadır. Türkçe ve Arapça arasındaki dil etkileşimi tek taraflı olmamiş her iki dil de birbirinden kelime almiş ve kelime vermiştir. Osmanli'da devlet işlerinde kullanılan resmi dil Osmanlı Türkçesi olsa da Osmanlı hakimiyeti altındaki diğer bölgelerde etki alanı geniş olan Türkçe, Farsça, Arapça, Rumca, Ermenice vb. diller de konuşulmaktaydr. Nitekim Osmanlı Türkçesi, içerisinde Arapça-Farsça sözcük ve dil bilgisi kurallarl içermesi sebebiyle adeta imparatorluk dili olmuştur. Bu durum Türkçenin Arap lehçeleri üzerindeki etkisinin boyutunu da şekillendirmiştir. Bu yönüyle Osmanlı Türkçesi, gerek doğrudan Türkçe kelimelerin gerek Farsça ve diğer batı dillerindeki birçok kelimenin Arap lehçelerine aktarımında aracı dil konumunda olmuştur. Hal böyle olunca Türkçenin Yemen bölgesi Arap lehçesinde dahi hem sözcük hem de yapı/ekler bağlamındaki etkisi diğer komşu Arap ülkelerinin lehçelerine (Suriye, Irak, Lübnan vb.) oranla azımsanamaz nitelikte ve nicelikte olmuştur. Türkçenin Yemen lehçesi üzerindeki etkisi günlük konuşma dilinin yanı sira Yemen bölgesi yerleşim yerleri-kabile adlarında ve kalıp ifadelerinde/atasözlerinde de müşahede edilmiştir.
\end{abstract}

Anahtar Kelimeler: Yemen, Arapça, Türkçe, sözvarlığı, ödünçlemeler.

\footnotetext{
1 Dr. Öğr. Üyesi, Çukurova Üniversitesi/İlahiyat Fakültesi/Temel İslam Bilimleri Bölümü/Tefsir Anabilim Dalı, ertugruldoner@hotmail.com, https://orcid.org/0000-0002-5657-9627

2 Arş. Gör., Osmaniye Korkut Ata Üniversitesi/İlahiyat Fakültesi/Temel İslam Bilimleri Bölümü/Arap Dili ve Belagati Anabilim Dali, yusuf.ozcanlar1@gmail.com, https://orcid.org/0000-0003-2909-8585
} 


\section{Giriş}

Mazisi çok eskilere uzanan Türk-Arap ilişkileri Osmanlı'nın Arap coğrafyasında hüküm sürdügü yıllarda daha da artmıştır. Diğer birçok alanda olduğu gibi her iki toplumun kültürlerinin ana unsurlarından olan dillerinde de etkileşimler olmuştur. Türkçe-Arapça arasındaki ilişki umumiyetle Arapçanın Türkçeye etkisi bağlamında ele alınmıştır. Arapçanın Türkçe üzerindeki tesirinin genelde Türkçenin yazı dilinde, Türkçenin Arapça üzerindeki etkisinin ise daha çok Arap halk dilinde yani lehçede olduğu söylenebilir. Dillerin yazı dilikonuşma dili', 'resmi dil-halk dili', 'kurala bağlı dil-kurala bağlı olmayan dil' şeklinde adlandırılan farklı iki boyutundan bahsedilir. Arap dilinde daha belirgin rastlanılan bu duruma dilbilimde 'iki dillilik' (diaglossia/ izdivâciyyetül-luğa) denilir (Watson, 2002, 8). Arap dilindeki iki dilli yapı, 'yazı dili-resmî dil' olan Fusha ve 'konuşma dili-halk dili' olarak bilinen Avamca/ lug̉atu'-‘āmmiyye şeklinde karşımıza çıkar (Alp, 2011, 93). Bu bakımdan Türkçe ve Yemen Arapçası arasındaki etkileşim dendiğinde özellikle Yemen'de konuşulan halk dili/ lug̉atu'l‘āmmiyye anlaşılmalıdır. Buradan hareketle çalışmada evvela Yemen tarihi ve Osmanlı-Yemen ilişkileri hakkında birtakım bilgiler verilecek, ardından bu iki kültür arasındaki etkileşimin özellikle dil yönü üzerinde durularak Yemen Arapçasında Türkçe unsurlar ele alınacaktır.

\section{Araştırmanın Amacı ve Yöntemi}

Araştırmada Yemen Arap lehçesinde varlığını sürdüren Türkçe unsurların tespiti amaçlanmıştır. Bu doğrultuda Yemen lehçesi, atasözleri, kabile ve yer adları üzerine hazırlanan muhtelif sözlükler taranmış, Yemenli katılımcılarla bireysel görüşmede bulunulmuş ve buradan hareketle de Yemen lehçesinde kullanılan Türkçe sözcük ve eklere ulaşılmaya gayret edilmiştir. Daha sonra tespit edilen kelimelerin alanlarına göre tasnifi yapılmış, her bir kelimenin Arap harfleriyle yazımına ve transkripsiyonuna yer verilmiştir. Ayrıca her sözcüğün Yemen Arapçasındaki anlamı verilmiş ve kaynağı gösterilmiştir.

Arapçanın muhtelif lehçelerinde (Suriye, Ürdün, Lübnan, Irak, Mısır, Cezayir, Libya vs.) kullanılan Türkçe unsurlar üzerine birçok çalışma yapılmıştır. Araştırmamızda doğrudan Yemen lehçesi Türkçe unsurlarını konu edindiğimizden farklı Arap lehçeleri ve Türkçe ilişkisine değinen diğer çalışmalara değinilmeyecektir. Yemen harici diğer Arap lehçelerinde Türkçe unsurları konu edinen çalışmaların genel listesine Güney (Güney, 2018, 8-13) ve Uysal'ın (Uysal, 2018, 115-121) eserlerinden ulaşmak mümkündür.

Doğrudan Yemen lehçesinde Türkçe unsurları araştıran, Arap dilinde yazılmış 2 makaleye ulaşılmıştır. Bunlar Yemenli araştırmacı İsmail b. Ali el-Ekva'nın 'Kelimāt Turkiyye fi'l-lehecāti'lYemāniyye' ve 'Kelimāt Turkiyye musta'mele fi't-Yemen' başliklı eserleri ile Abbas Ali esSûsuva'nın 'Bākāya el-elfäz et-Turkiyye fi'l-mahkiyyetil'-Yemeniyye' isimli çalışmasıdır. Ekva tarafından kaleme alınan iki makale aslında birbirinin aynısıdır. Ekva bu çalışmasında Yemen lehçesinde kullanılan 168 Türkçe kelimeye yer vermiş ve kelimelerin tasnifinde alfabetik düzeni esas almıştır. Sûsuva ise çalışmasında 133 Türkçe kelime örneğine değinmiş ve Ekva'da olduğu gibi bu kelimeleri alfabetik düzene göre sıralamıştır. Araştırmamızda bu iki çalışmaya ek olarak Mathar Ali el-İryânî̀nin genel Yemen lehçesi kelimelerini topladığı $M u$ 'cemu'l-Yemenî' fi'tlug̉a 
ve't-terās adlı sözlük çalışması da taranmış; ancak bu eserde Türkçe kelimeye rastlanılmamıştır. Çalışmamızda Arap lehçelerinde Türkçe ekler konusuna da değinilmiştir. Bu doğrultuda Mısır, Suriye ve Irak lehçesinde Türkçe eklerin kullanım örneklerine yer verilmiş; bunların Yemen lehçesinde kullanılan Türkçe eklerle karşılaştırılması yapılmıştır. Ayrıca Yemen atasözleri ve Yemen kabile, yerleşim yerleri adları sözlükleri de incelenmiştir. Burada Yemen lehçesinde daha önceki dönemlerde dahīl olmuş, kullanılmış; ancak günümüze ulaşmamış olan Türkçe sözcüklerin de tespiti amaçlanmıştır. Bunlara ek olarak çeşitli kaynaklardan derlemiş olduğumuz Türkçe tabirlerin Yemen lehçesinde kullanım durumunu belirlemek üzere Yemenli 5 katılımcıyla bireysel görüşme yapılmıştır. Yapmış olduğumuz bireysel görüşme neticesinde yazılı kaynaklarda rastlamadığımız; ancak katılımcıların lehçede kullanıldığını belirttiği bazı Türkçe kelimeler de çalışmamıza dâhil edilmiştir. Neticede farklı kaynaklardan yapmış olduğumuz kapsamlı inceleme sonucunda Yemen lehçesinde 296 Türkçe kelime kullanıldığı görülmüştür. Araştırmamızda Yemen lehçesinde Türkçe unsurların belirlenmesinde başvurduğumuz kaynaklar şunlardır:

el-Ekva‘, İsmail b. Ali, "Kelimāt Turkiyye fi'l-lehecāti'l-Yemāniyye", "Kelimāt Turkiyye musta'mele fìl-Yemen"; es-Sūsuva, Abbas Ali, "Bākāya el-elfāz et-Turkiyye fi'l-maḥkiyyeti'lYemeniyye”; el-İryān̄̄, Mathar Ali, el-Mu'cemu'l-Yemenī fi't-luġa ve't-terās Ahmed, Mu'cemu'l-büldān ve'l-kabāili'l-Yemeniyye; 'Anān, Zeyd b. Ali, el-Lehcetu'l-Yemāniyye fi'nnuket ve'l-emsāli’ș-Șan'āniyye; el-Ekva', İsmail b. Ali, el-Ems̄ālu'l-Yemāniyye; Allūb, Abdulvehhāb, Mu'cemu'd-dahĭl fi'l-âmmiyyeti'l-Mısriyye; Mahfūz, Hüseyin Ali, "el-Elfãżu'tTurkiyye fill-lehecāti'l-Irākıyye”; Abduddāyim, el-Kelimātu't-Turkiyye fì kavāidi'l-luġati'l-'Arabiyye ve'l-lehceti's-Sūriyye; el-Esedī, Muhammed Hayruddîn, Meusū'atu Haleb el-mukārane; Abdurrahim, Yasin, Mavsu'atu'l-‘āmmiyyeti's-Sūriyye; K1, Kişisel Görüşme, 30.08.2020; K2, Kişisel Görüşme, 22.07.2020; K3, Kişisel Görüşme, 25.08.2020; K4, Kişisel Görüşme, 12.08.2020; K5, Kişisel Görüşme, 15.09.2020.

\section{Genel Hatlariyla Yemen Tarihi}

\subsection{Yemen Kelimesinin Anlam Alanı}

Arap Yarımadası, Antik Grek ve Romalı coğrafyacılar tarafından genel olarak Arabia Felix, Arabia Petrea ve Arabia Deserta şeklinde üçe ayrılmış; Arabia Felix bugünkü Yemen ve ona ek olarak Mehra ve Hadramevt topraklarını da içine alan bölgeye, Arabia Petrea Hicaz topraklarına, Arabia Deserta ise Arabia Felix olarak isimlendirilen bölgenin kuzeydoğusundan Firat nehrine kadar ulaşan Suriye-Mezapotamya çölünü kapsayan bölgelere ad olarak verilmiştir (Playfair, 1859, 1; Porter, 1986, 3; Thomas, 2013, 2-3; Yavuz, 2003, 60). Bu coğrafyacilar tarafindan mutlu/mesud Arabistan olarak tanımlanan Arabia Felix’in; batısında Kızıldeniz, güneyinde ise Hint Okyanusu, Umman Denizi ve Aden Körfezi ile sınırı olup, kuzeyinde Suudi Arabistan ve doğusunda ise Umman yer almaktadır (Sırma, 1982, 427; Kurt, 2013, 400-401). Bulunduğu konum itibariyle dünya denizlerinde taşınan malların büyük bir kısmını kapsayan suyollarına sahip Yemen; Bâbu'l-Mendeb Boğazını ve Aden Körfezini kontrol olanağının yanı sıra Doğu 
Afrika ile Arabistan Yarımadası arasında bir geçiş noktası olan önemli bir bölgede yer almaktadır (Sırma, 1993, 13/377; Aydın-Ergün, 2017, 5).

İbn Manzûr'un Lisânu'l-Arab ve Zebîdî'nin Tâcu'l-Arûs adlı eserlerinde Yemen kelimesinin bereket anlaminda el-yümn kökünden geldiği ifade edilmiştir (İbn Manzūr, 6/4967; Zebīdī, 2001, 36/302). Yemen'in coğrafi yapısını Serat adı verilen dağlık ve Tihame denilen ovalık bölge ile Kızıldeniz ve Hint Okyanusu'nun Arap Yarımadasındaki kıyı şeridi oluşturmaktadır. Serat oldukça verimli ve yerleşime uygun ve bunun zıddı Tihame bölgesi geniş, kumlu ve yağmur yağmayan bir bölge olmasına rağmen Yemen, Arap Yarımadası'nın en verimli; ağaçlarının, meyvelerinin ve ürünlerinin bol olması gibi sebeplerden ötürü Yemenü'l-Hadrâ yani Yeşil Yemen olarak da nitelendirilmiştir (Hamdānī, 1990, 90; Curafî, 1987, 41; Kadri, 1910, 14; Barlak, 2013, 334). Hicaz bölgesinde güneşe doğru dönüldüğünde, kuzeyde kalan Şam’a karş1lık bu bölgenin güneyde yani sağ tarafta kalması sebebiyle Yemen isminin Arapçadaki sağ el anlamına gelen yedu'l-yümnâ ifadesinden geldiği ayrıca genel olarak Mekke'yi dünyanın merkezi kabul eden İslam coğrafyacılarına göre doğuya doğru dönüldüğünde Kâbe’nin güneyinde yani sağında kaldığından sağ anlamındaki el-yemîn ve güney anlamındaki yemnetün kelimesinden aldığ1 belirtilmiştir (Sırma, 1993, 13/371). Ayrıca Yemen b. Kahtân'dan hareketle bölgeye Yemen denildiği ifade edilmiştir. Bölge insanlarının, Hz. Nuh'un oğullarından Sâm soyundan geldikleri rivayet edilmiştir. Tufan'dan sonra Sâm, Güney Arabistan Yarımadasına yerleşmiş ve bu insanlar Arap halkını oluşturmuşlardır. Sâm'ın nesli Arab-1 Bâîde, Arab-1 Arîbe, Arab-1 Müsta'ribe ve Arab-1 Müsta'cime olmak üzere dörde ayrılmış; Yemenlilerinin neslinin Arab-1 Arîbe'den oldukları, soylarının da Hz. Nuh'un torunlarından Eber'in oğlu Kahtan'a dayandığı ifade edilmiştir (Sırma, 1982, 38).

Genel olarak Yemen kelimesinin özellikle "sağ yan" ve/veya "güney" anlamları ile ilişkisi olduğu yönünde görüşler ağır basmaktadır (Tomar, 2013, 43/402). Bu bağlamda Hz. Peygamberin, Tebük yakınındaki bir tepenin üzerine çıkıp, kuzeyi göstererek "Bütün buralar Şam'dır.", sonra da güneye dönerek "Bütün buralar Yemen'dir." demesi sebebiyle, Yemen isimlendirmesinin yön belirtmeye karş1lık geldiğini söylemek mümkündür (Sirma, 1993, 13/371). Bununla birlikte Hz. Peygamber”in "İman Yemenlidir, hikmet Yemenlidir." (Buhārī, "Menākıı", 1; Müslim, "īmān", 82-84-88-89-90) ve "Size Yemenliler geldi. Onlar ince ruhlu ve yufka yürekli insanlardır..." (Buhārī, "Menākıı", 1; "Meġāzī", 74; Müslim, "īmān”, 84, Tirmizī, "Fiten", 61) başlangıcıyla başta iman olmak üzere hikmetin Yemenli oluşunu belirten hadisten (bk. Demirci, 2011, 95-122) Hz. Peygamber'in Yemenlileri ince ruhlu, yufka yürekli olmalarıyla övdügü ifade edilmiş; Yemenlilerin ince ruhlu, yufka yürekli olmaları yerleşik hayata geçmiş, şehirleşmiş olmalarının bir neticesi olarak gösterilmiştir (Kurt, 2001, 99). Yerleşik hayata geçen ve medenileşen Yemen için, hadisin başında geçen "kalp yönüyle kabalık, anlayış yönüyle kıtlığın deve besleyenlerde yani bedevilerde, görgü ve beşerî münasebetlerin ise koyun besleyenlerde olduğu şeklinde remzedilen şehirleşmeye" dikkat çekilmiştir (Aynī, trs., 16/72). 


\section{2. İslamiyet’ten Önce Yemen'de Kurulan Baz1 Önemli Devletler (Main, Sebe ve Himyerî)}

Arap Yarımadası'nın güneyinde yer alan Yemen, diğer bölgelere nazaran yaşamaya, tarıma elverişli yerler arasında yer almış (Aydın, 1991, 49), bu sebeple Yemen, tarihin en eski yerleşim alanlarından biri olmuş ve kaynaklarda Yemen ve çevresindeki yerleşik hayatın M.Ö. 5000'lere kadar uzandığı belirtilmiştir. Açıkçası yukarıda da ifade ettiğimiz üzere yaşamaya ve tarıma elverişli olması sebebiyle tarih içerisinde birçok devlet ve kabileye ev sahipliği yapan bölge, felix isimlendirmesinin "Bereket" anlamındaki tercümesinin karşılığıdır da denebilir (Zeydan, trs., 139). Yemen, tarih içerisinde Main, Sebe ve Himyerî gibi birçok devlete ev sahipliği yapmıştır (Es‘ad, 1983, 62-64; Yiğit, 2009, 36/241-243). Bu devletlerin kuruluş ve yık1lış tarihleri kesin olarak bilinmemekle birlikte tarihçiler tarafindan bazı zaman aralıkları zikredilmiş ve İslam öncesi Yemen'de tüm devletlerin Sebe ismiyle zikredildiği belirtilmiştir. Bu durumun Arabistan'in genel olarak Yemen şeklinde isimlendirilmesinin bir neticesi olduğu söylenebilir (Abdullah, 2003, 3/1563).

Yemen'de ortaya çıkan en eski devletlerden olan Main Krallığı (yaklaşık M.Ö. 1400-650), Hicaz, Fedek ve Teyma sınırlarına kadar genişlemiş, kendileriyle aynı dönemde varlığını sürdüren Fenikeliler gibi ticari faaliyetlerde önemli bir alana hâkim olarak ekonomik anlamda bir güç haline gelmiştir. Doğudan aldıkları malları Umman Denizi, Basra Körfezi, Fırat ve Dicle Nehirleri ve Kızıldeniz yolu ile Fenikelilere, Misırlılara, Asurlulara ve diğer bazı bölgelere ulaştırmaktaydılar. Ayrıca diğer birçok bölgelere taşınacak olan ürünler Yemen üzerinden hareketle pazarlanmaktaydı (Çağatay, 1957, 7-9; Barlak, 2013, 16; al-Haidari, 2016, 18).

Yemen'de kurulan devletlerden bir diğeri ise Sebe Devleti'dir (M.Ö. X. yüzyıl öncesi-115). Ticaretin en önemli ekonomik unsur olduğu Sebeliler, Kuzey Arabistan ticaretine hâkim bir yapıya sahipti. Yemen'den kalkan ticaret kervanları Kuzey Arabistan yoluyla Akdeniz kıyılarına geçmekte, o dönemde önemli bir ticaret mahalli olan Gazze ile birçok ticari ilişkiler kurmaktaydı (Çağatay, 1957, 11; Tomar, 2013, 43/402). Deniz yollarına ve Muson rüzgârlarına hâkimiyetleri sebebiyle "Güney Denizlerinin Fenikelileri” olarak nitelendirilmişlerdir (Hitti, 2011, 86). Ticaretin yanı sıra ziraat ve imar faaliyetlerine de yer veren Sebelilerin, köşkler, mabetler, kaleler ve barajlar -hatta meşhur Me'rib Su Seddi'ni onların yaptığı ifade edilmiştir- (Çağatay, 1955, 5253) inşa ettikleri ayrıca lükse düşkün oldukları belirtilmiş, ev ve mabetlerini altın, gümüş ve kıymetli birçok taşlarla süsledikleri rivayet edilmiştir. Hatta bu anlamda Sebe "Altın Ülkesi" olarak adlandırılmıştır (Tkatsch, 1988, 10/273).

Güney Arabistan'da kurulan ve yaklaşık olarak M.Ö. 115-M.S. 525’li yıllarda varlık alanı bulan Himyerî Devleti, İslamiyet’in doğuşundan önce kurulan Arap devletlerinin en büyüğü, en güçlüsü olarak ifade edilmektedir. Himyerîler, Çin-Hint, Roma-Bizans arasındaki ticaret yolları üzerinde bulunduğundan birçok farklı kültürlerle etkileşim içerisinde olmuşlardır (Hizmetli, 1991, 59; Algül, 1998, 18/62). Himyerîlerin dokumacılık, madeni eşya ve kılıç imalatında ileri bir seviyede oldukları, "Kaleler Ülkesi" olarak nitelendirildikleri (Barlak, 2013, 335), yaptıkları bent ve su kanalları sayesinde tahıl ve meyve üretiminde büyük başarı elde ettikleri anlatılmış, şiir ve fesahat gibi sözlü kültürün önemli yapıtlarında oldukça başarılı oldukları dile 
getirilmiştir. Ticari ve sosyal ilişkilerin yanı sıra savaşçı özellikleri ile de dikkat çeken Himyerîler, Habeşliler ve İranlılar ile de sık sık mücadele içerisine girmiş; hatta Habeşistan'ı hâkimiyetleri altına almış, Mısır’a kadar ilerlemişlerdir (Çağatay, 1957, 14). Farklı kültürlerin etkileşim alanı haline gelen Himyerîler'in genel olarak Ay'a, Güneş'e, Aştar’a (çoban yıldızı) taptıkları ayrıca özellikle bu dönemde Güney Arabistan’a Yahudiliğin, kısmen de Hiristiyanlığın girdiği ifade edilmiştir ${ }^{1}$. Bölgeye Hıristiyanlığın II. Konstantin zamanında (337-361) girdiği; San’a, Aden, Merib ve Zafar'da birçok kilise inşa edildiği belirtilmiştir. Hiristiyanlık özellikle Necran bölgesinde yayılmış, Bizanslılarla Habeşlilerin iş birliği yapması ve Güney Arabistan'da siyasi emellerinin olması gibi nedenlerle Himyerî hükümdarlarının Yahudiliğe meyletmelerine sebep olduğu aktarılmıştır (Algül, 1998, 18/62). 523 yılında Himyerî hükümdarı Zu Nüvas, Hıristiyanlığı ortadan kaldırmaya teşebbüs etmiş, Necran'daki Hıristiyanlara şiddet uygulamış; Yahudiliğe geçmeyi kabul etmeyen (farklı kaynaklarda) 4000 ile 20000 arasında insanı ateş çukuruna attırmıştır (Eroğlu, 1991, 30/471; Hizmetli, 1991, 59). Zu Nüvas'in yaptığ1 bu şiddet üzerine Habeş Necâşîsi 525 yılında Eryat kumandasında, içerisinde Ebrehe'nin de bulunduğu bir ordu göndermiş ve Yemen'i fethetmiştir. Daha sonra Eryat ile Ebrehe'nin arası açılmış, halkın desteğini alan Ebrehe, Eryat'i öldürerek Yemen idaresini ele geçirmiştir. Koyu bir Hıristiyan olan Ebrehe, Hıristiyanlığ1 yaymak adına San'a'da Kalîs/Kulleys adında bir kilise yaptırarak Arapların kutsal addettikleri Kâbe yerine insanları bu kiliseyi tavaf etmeye zorlamış, Mekkelilerin giderek gelişen ticari faaliyetlerine engel olmak ve San'a'yı hem ticari hem de dini bir merkez yapmak adına girişimlerde bulunmuştur (Kazanc1, 1994, 10/79-80; Çağatay, 1955, 54-57). Hatta sonrasında da Kâbe'yi yıkmak adına Mekke'yi kuşatmış ve Kur'an'ı Kerim'de Fil suresinde de belirtildiği üzere bu emeli başarısızlıkla sonuçlanmıştır (Çağırıcı, 1996, 13/69-70). Bu olaydan sonra Yemenliler Habeşlilere karşı İran'dan yardım istemiş, Enuşirvan Yemen'e bir ordu göndererek bölgeyi hâkimiyetine almış ve burada yaklaşık elli yıl kadar İran hâkimiyeti devam etmiştir (Çağatay, 1957, 16-17).

Sonuç olarak, İslam öncesi Yemen'de kurulan devletler birçok deniz yollarının etrafında konuşlanmış olmaları sebebiyle başta ticaret ve ziraat olmak üzere ekonomik olarak önemli gelişim sağlamış, el eşyaları, imar faaliyetleri gibi alanlarda ilerlemiş, dil, şiir ve fesahat gibi konularda da kültürel başarılar, atılımlar gerçekleştirmişlerdir. Kutsal metinlerde, özellikle de Kur'an'1 Kerim'deki bazı sûrelerde tarihte önemli bir yere sahip olan Yemen'de yaşamış toplumlardan ve/veya burada gerçekleşen birtakım olaylardan söz edilmiştir. Bu bağlamda Güney Arabistan'da kurulmuş olan Ad kavmi ve bu kavme gönderilen Hz. Hud (A'rāf 7/65-72), İrem şehri (Fecr 89/ 6-8), Salih peygamberin gönderildiği Semud kavmi (A'rāf 7/73-79; Neml 27/45-53; Hūd 11/61-68), Hz. Süleyman ve Sebe Melikesi Belkıs görüşmesi (Neml 27/22-44), Sebelilerin yaptırdığı Me'rib Su Seddi'nin Arîm seli ile yıkılması (Sebe 34/15-17) ve daha önce de bahsettiğimiz üzere Yemen'den yola çıkan Ebrehe'nin fillerden oluşan ordusuyla Kâbe'yi yıkmaya çalışması (Fīl 105/1-5) gibi başlıklar bölgenin önemini ortaya koyması açısından dikkat çekicidir.

\footnotetext{
1 Yemen bölgesinde Yahudilik ve Hıristiyanlığın varlığına dair geniş bilgi için bk (Döner, 2014, 209-232; Yazıc1, 2019).
} 


\section{3. İslamiyet'in İlk ve Erken Dönemlerinde Yemen (Osmanlı Devleti’ne Kadar Olan Dönem)}

610 yllında İslamiyet’in zuhuru ile birlikte Arap Yarımadasında başta dini olmak üzere, sosyal ve siyasi açılardan birçok değişiklik meydana gelmiş, zamanla başta Kureyş olmak üzere diğer çevre bölgelerde bazı kabileler İslam'a girmeye başlamıştır. Hz. Muhammed'in bu süreçte bazı devletlere İslam'a davet mektupları gönderdiği, bunlardan birinin de Yemen'deki Sâsânîler olduğu bilinmektedir. 628 yılında Sâsânî valisi Bazan, İslam’’ kabul etmiş, 629 yllında Himyerî krallarına da davet mektupları gönderilmiş, Yemen halkı zamanla İslamiyet’i kabul etmeye başlamış ve Yemen Müslümanların kontrolüne geçmiştir (Fayda, 1982, 66-76). Hz. Muhammed, Yemen'e hem İslam'ı anlatmaları, hem buranın kontrolünü sağlamları hem de vergi toplamaları için sahabilerden Hz. Ali, Ebû Mûsâ el-Eş'arî, Muaz b. Cebel gibi önemli birtakım kimseleri yollamıştır (Sırma, 1993, 13/374).

Hz. Muhammed'in vefatına yakın dönemlerde başlayan irtidat hareketleri onun vefatını müteakip geniş bir bölgeye yayılmıs, daha önce Yemen'de İslam’ı kabul etmiş bazı kabileler irtidat ettiklerini, bazıları ise zekât vermek istemediklerini dile getirerek yönetime başkaldırmışlardır. Hz. Ebubekir, bu eğilimleri başarılı bir şekilde bastırmış, Arap kabileler arasındaki iç çekişme ve ayrılmalara firsat vermemek üzere bir politika takip etmiştir. Hz. Ömer döneminde de benzer bir idari yapı hâkim olmuş, bölgeye gönderilen vali ve komutanlar buradaki yapıya önemli katkılar sunmuş hatta Kuzey Afrika'nın fethi gibi ilk dönem İslam fetihlerinde Yemenli kabileler önemli rol oynamışlardır (Apak, 2007, 86-97).

Hz. Osman döneminde kabileler arasında gözetilen hassas dengenin belirgin bir şekilde Kureyş ve dahası Ümeyyeoğulları lehine çevrilmesinin ardından yaşanan başkaldırılarda ve Hz. Ali'nin halifeliğe geçişi esnasında ve sonrası yaşanan iç karışıklıklarda Yemenli kabilelerin önemli etkileri olduğundan bahsedilmiştir. Daha çok Hz. Ali etrafında konuşlanan Yemenliler, onun halife olması hususunda etkin rol oynamıs, hatta $\mathrm{Hz}$. Ali ile Muaviye arasında gerçekleştirilen Siffin Savaşında önemli bir komutan olan Eş'as b. Kays ve savaş sonrasında gerçekleşen hakem olayında hakemlik yapan Mûsâ el-Eş'arî, Hz. Ali tarafinda olan Yemenli kimselerdendir (Barlak, 2006, 115-125). 661 yılında Hz. Ali'nin şehit edilmesi Yemen halkını derinden etkilemiş ve bu süreçte Yemen üç kısma ayrılmıştır. Daha sonra Muaviye b. Ebî Süfyan iktidarı ele geçirmiş, Emevîler dönemi başlamış, Muaviye, Cened ve San'a'yı birleştirmiştir. Emevîler yaklaşık 90 yıl Yemen’i yönetmiştir (Tomar, 2013, 43/404). Emevîler’in yıkılması sonrası Yemen'de Şiilerin Zeydî mezhebi ortaya çıkmış ve Zeydîler Devleti kurulmuştur (Üzüm, 2013, 44/326-328). İlk dört halife döneminin ardından yaşanan dini-siyasi birtakım olaylar, kabile yönetiminin etkin olduğu Yemen'de bölgesel ayrıllkları tetikleyici bir hale dönüssmüss, devletin valileri halka baskı uygulamak zorunda kalmış, özellikle Abbasiler dönemi ve sonrasında Yemen iç karışıklık ve isyanların çıktığı bir yere dönüşmüştür (Sirma, 1982, 4546). Abbasiler döneminde Yemen bölgesinde yerel liderlikler ortaya çıkmış; Zebîd merkezli Ziyâdîler, Şibâm Kevkebân merkezli Ya'furîler ve yine Zebîd merkezli Necâhîler Abbasi hilafeti otoritesi içerisinde varlık alanı bulmuşlardır (el-Cuhenī, 1986, 29). 
Yemen'de Abdü'n-Nebi b. Mehdi adında birisi zuhur etmiş, kendi adına hutbe okutmuş ve tüm dünyayı yönetme hevesi ile birçok yeri istila etmiştir. Bunun üzerine Eyyûbî Devleti sultanı Selahaddin Eyyûbî güçlü bir ordu kurarak Yemen'e göndermiş ve burayı fethetmiştir. Eyyûbîler tarafindan ele geçirilen Yemen'de Resûlî ailesine mensup kimseler bazı şehirlere vali olarak atanmış, Mekke valisi Nureddin Ömer b. Ali er-Resûlî, son Eyyûbî hükümdarı Selahaddin Yusuf'un vefatı üzerine Yemen hâkimiyetini ele almış, Yemen'de yaklaşık iki yüz yıl sürecek Resûlî Devletini kurmuştur (Tomar, 2009, 225). Bazı tarihçiler tarafından Resûlîlerin Arap asıllı oldukları söylenmekle birlikte, hanedan mensuplarının Türkçe konuşmalarına istinaden Selçuklu muhacereti ile bölgeye gelen Oğuzların bir boyuna mensup Türkmenler olabileceği ya da Türkmenlerin yaşadığı bölgelere yerleştirilen Arapların zamanla kimliklerini yitirerek Türkçe konuşmaya başladıkları yönünde fikirler de mevcuttur (Tomar, 2008, 16/1-2). Resûlîler, Yemen'deki birçok yönetimin aksine sünnî bir yol izlemiş, pek çok âlim yetiştirmiş, kurdukları medrese ve kütüphanelerle bölgede önemli ilmi ve kültürel faaliyetlerde bulunmuşlardır. Hatta ziraatın yanı sıra farmakoloji, veterinerlik ve astronomi gibi alanlarda oldukça ilerleme kaydetmişlerdir. Daha sonra 1454'te Yemen'de Tâhirîler Devleti kurulmuş, 1517'ye kadar hüküm sürmüşlerdir (Tomar, 2009, 227-234-235).

\subsection{Yemen'de Osmanlı Dönemi}

Yemen, Avrupa-Uzakdoğu ticaret yolu üzerinde olması nedeniyle birçok devletin üzerinde emelleri olduğu bir yapıya sahiptir. Bu ticaret yollarının kıyısında Kızıldeniz ile sınırı olan Yemen, Ümit Burnu'nun ve Amerikan'in keşfine rağmen her daim canlı kalabilmeyi başarmıştır. Ümit Burnu'nun keşfedilmesiyle Avrupa, özellikle donanmasıyla meşhur Portekiz, Doğu'nun zenginliklerinden faydalanmak ve bu zenginlikleri Batı'ya aktarmak, dahası İslam dünyasını kuşatmak ve Hıristiyanlığı yaymak adına Hindistan ve Yemen kıyılarını ele geçirmeye çalışmıştır. Bu dönemde Memlükler, deniz gücü üstünlüğünü elinde bulunduran Portekizlilere karşı başarılı olamamış, 1517'de Portekizliler Cidde'ye kadar ulaşmış, İslam dünyasının önemli merkezlerinden olan bu bölge Hıristiyan bir devletin egemenliği altına girmiş, Mekke ve Medine Portekiz tehlikesiyle karşı karşıya kalmıştır (Özbaran, 1978, 71-75; Sırma, 2013, 433-434). Bu dönemde Osmanlı Devleti, Mısır ve Suriye bölgelerini kontrolü altına almış ve Arap Yarımadasında yayılmaya başlamıştır. $\mathrm{Bu}$ ilerleme Portekizlilere tehdit oluşturmuş ve Portekizlilerin yayılma politikalarına engel olmuştur. Mısır'in 1517'de Yavuz Sultan Selim Han tarafindan ele geçirilmesi üzerine Emir İskender, Yemen'e başkomutan tayin edilmiştir (Hatipoğlu, 2004, 20-23). Bölgede çeşitli mücadeleler verilmiş ayrıca kendinden bir vali ve asker göndermeyen Osmanlı Devleti bölgede bağımsızlıklarını ilan eden topluluklarla da ilgilenmek durumunda kalmıştır. Osmanlı Devletinde taht değişikliği yaşanmış, Yavuz Sultan Selim'in vefatı üzerine tahta Kanuni Sultan Süleyman geçmiştir. Kanuni, Mısır Valisi Hadım Süleyman Paşa komutasındaki orduyu Yemen'e göndermiş, Gazze Sancak Beyi Bıyıklı Mehmet Paşa'nın oğlu Mustafa Bey'in yardımıyla Zebîd ve Aden bölgelerini de içine alarak Yemen'de Osmanlı yönetimi (1538-1539) kesin olarak başlamıştır (Yıldırım, 2001, 8-52). Bölge sadece dış güçlerin olumsuz etkileri altında kalmamış, içeride birçok mezhebi isyan çıkmış (Ünal, 2018, 17-20); 
farklı zamanlarda Yemen birçok bölgeye ayrılmış ve yaşanan bu durumlar yönetimi zor durumda bırakmıştır. Uzunca bir süre (yaklaşık 1635-1849) Zeydiler bölgede etkin bir rol üstlenmişlerdir (Barlak, 2013, 31; Aydın-Ergün, 2017, 11; Gökalp, 2013, 87-114).

1869'da Süveyş Kanalı'nın açılması, Osmanl1-İngiliz siyasetini olumsuz etkilemiş, Yemen bölgesinde üst edinmek isteyen İngiltere kömür deposu yapmak bahanesiyle Aden'e yerleşmeye başlamıştır. İngilizlerin, Asîr'de İdrîsî isyanını desteklemesi, Nevâhi-i Tis'a şeyhleriyle anlaşması Osmanlı Devleti'ni bölgede zayıflatma amacını taşımaktaydı. Osmanlı Devleti de bölge siyasetini tekrar gözden geçirmeye başlamış, Yemen'de yönetimi kontrol altına alma çabası içerisinde olmuştur. Bu dönemde Osmanlı Devleti ile Zeydî imamlar üzerinden savaşlar başlamış, Hudeyde bölgesi kontrol altına alınmış, Osmanlı Devleti siyasi ve idari islahatlar yapmıştır. 1872 'de San'a'ya yeniden girilmiş ve burası yönetim merkezi yapılmış, Yemen'de Yedinci Ordu kurulmuştur (Bostan, 2013, 43/411; Hatipoğlu, 2004, 26). Bu tarihten itibaren Yemen'de Osmanlı hâkimiyeti kurulmuş olmasına rağmen imamlar isyan etmeye devam etmiş, bu isyanlar İngilizler, Fransızlar ve İtalyanlar tarafindan kullanılmış, dolayısıyla aşiret isyanları Osmanlı Devleti'ne ciddi sıkıntılar oluşturmuştur. Bu ve ilerleyen süreçlerde Osmanlı Devleti bölgedeki karışıklık ve isyanları bastırmak ve istikrar sağlamak adına buraya birçok vali atamak zorunda kalmış (Barlak, 2013, 64-99), isyanları bastırmak için sayısı hakkında ciddi rakamların telaffuz edildiği pek çok askerini bölgeye göndermiş ve burada ciddi kayıplar vermiştir. Hatta Yemen "Türkler Mezarlığı" olarak anılmaya başlanmıştır (Sırma, 1982, 66; Coşkunoğlu, 2015, 44). Birinci Dünya Savaşı'nda on binlerce vatan evladına mezar olan Yemen'de 1911 yılında imzalanan Daan Antlaşması ile yıllardır akan kan durmuş, 1918'de Mondros Ateşkes Antlaşması'nın neticesinde Yemen ve Asîr'deki Osmanlı kuvvetlerinin İhtilaf Devletleri garnizonuna teslim olmaları ile de Yemen'de Osmanlı Dönemi kapanmıştır. Bu tarihten itibaren Kuzey Yemen bağımsızlığını kazanarak Zeydî imamlar tarafından idare edilmeye başlanmış, Güney Yemen ise 1967 yılına kadar İngilizlerin hâkimiyetinde kalmıştır (F1çıc1, 2009, 89).

Osmanlı Devleti zamanında Yemen'de ortaya çıkan birçok isyan ve sıkıntıya rağmen birçok dini, askeri, idari ve içtimai yapılar inşa edilmiş, ciddi yatırımlar yapılmıştır. Bu dönemde San'a'nın batı bölgesinde Osmanlı memurlarının yaşaması için Türk Mahallesi kurulmuştur. Özdemir Paşa, San'a'da bir cami ve medrese yaptırmış, Murad Paşa bir cami ve sebil, Sinan Paşa büyük bir kasır, Hasan Paşa Bekiriye adında bir cami (Günel-Dişli, 2011, 155-170), bir hamam, mescid ve han, Fazlı Paşa San'a'da Bi'r-i Bâşâ isminde bir su kuyusu, Terîm'de bir cami, Ferhad Paşa Zemâr'da bir kasır yaptırmışlardır. 19. yüzyılın sonlarından itibaren San'a, Hudeyde ve Ebhâ'da hastane ve eczaneler, Hudeyde, Muhâ ve Kemeran'da karantina alanları açılmıştır. San'a'da II. Abdülhamid Han adına Hamidiye Camii ve çeşitli binalar inşa edilmiştir. Eğitim alanında sancak merkezlerinde rüşdiye ve idâdîler, kaza ve nahiyelerde sıbyan mektepleri, San'a'da dâru'l-muallimîn ve sanat mektepleri faaliyete geçirilmiştir. Ulaşım ve üretilen mahsüllerin sahile nakliyatını kolaylaştırmak için Hudeyde ve San'a arasında inşa edilmesi planlanan demiryolu Hâcile'ye kadar gelebilmiştir. Osmanlı Devleti'nin son dönemlerinde tuz elde etmek için su kanalları açma, Kızıldeniz sahillerindeki yer altı madenlerini çıkarma, Me'rib'de baraj yapma gibi projeler bölgede yaşanan isyan ve sıkıntılar 
nedeniyle hayata geçirilememiştir. Yemen, pek çok Osmanlı askeri, valisi, sancak beyi ve idarecilerinin yaşadığı ve hatta vefatlarını müteakip defnedildiği bir vatan toprağı olmuştur. Bugün hala sayısı azımsanamayacak kadar bir Türk nüfusunun bölgede yaşamaya devam ettiğini de söyleyebiliriz (Bostan, 2013, 43/412).

\section{Yemen Lehçesinde Türkçe Unsurlar}

Toplumlar arası ticari, ekonomik, kültürel, siyasi vb. ilişkilerle göçler, seyahat, evlenme vb. bireysel faaliyetler tabii olarak diller arası etkileşim/dil teması ile sonuçlanır. Diller arası etkileşim özellikle son zamanlarda teknolojinin gelişmesi, radyo, televizyon, internet vb. kullanımının artmasıyla daha yoğun bir hal almıştır. Dil etkileşimi daha çok kaynak dilden alıcı dile söz varlığı aktarımıyla sınırlıdır. Bir dilin diğer bir dil üzerindeki söz varlığı etkisi genelde kendi kültüründe bulunmayan unsurlara dair sözcükler, argo, uzmanlık alanı olunmayan bir sahaya yönelik terimlerin aktarılması suretiyle olur. (Sarı, 2013, 4). Dil etkileşimi a) dilin korunması (sözcük transferi yapılsa da dilin ses, yapı, dizimi ve söz varlığı korunur), b) dil değiştirimi (toplum kendi dilini konuşmayı keser ve günlük hayatta kaynak dili kullanmaya başlar) ve c) yeni bir iletişim dili oluşması (alıcı dilin ses, yapı ve dizimde ciddi değişikliklere maruz kalması) olmak üzere üç farklı şekilde sonuçlanır. Dil temasları sonrası dil değiştirimi ve yeni bir iletişim dili oluşması aslında dil ölümü anlamı taşır (Winford, 2003, 11). Bu cümleden dil etkileşimine maruz kalan her dilin yok olacağı anlamı çıkarılamaz. Aslında dünyada konuşulan bütün diller birbiriyle olan ilişkileri sayesinde sürekli değişim ve gelişim durumundadır. Diller bu değişim ve gelişim ekseninde canlılığını korur. Dolayısıyla burada önemli olan diller arası etkileşimin yoğunluğu ve boyutudur. Yukarıda da değindiğimiz gibi etkileşime tamamen kapalı olan diller ile etkileşimin ses, biçim ve dizimi tamamen değiştirecek boyutta olduğu diller risk grubundadır.

Yeryüzünde konuşulan bütün diller gibi dil temasının boyutu ve yoğunluğu da durağan değildir. Belirli bir dönem birbiriyle yoğun dil teması içerisinde bulunan toplumlarda; ilişkilerin zayıflaması, göç, savaş, dini ve kültürel yapıda değişiklik vb. gerekçelerle zamanla dil etkileşimi azabilir veya tamamen ortadan kalkabilir. Şöyle ki bir zamanlar Osmanlı ile askeri, ekonomik, kültürel, siyasi vs. yönden güçlü ilişkisi olan Yemen; ilgili dönemde Osmanlı Türkçesinin söz varlığı unsurlarından etkilenmiş ve zamanla Yemen halk dilinde birçok Türkçe kelime kullanılır olmuştur. Osmanlının Yemen'den çekilmesini takiben diğer ilişkilerde olduğu gibi dil ilişkisinde de etkileşimin yoğunluğunda azalma gerçekleşmiştir. Bununla birlikte genel anlamda ArapçaTürkçe arasındaki etkileşim sadece Osmanlı'nın Yemen'de hüküm sürdüğü döneme hasredilemez. Nitekim Türklerin İslamiyetle tanışması Türk-Arap ilişkilerinde adeta bir dönüm noktası olmuştur. İlk etapta dinî içerikli kelime aktarımı ile başlayan bu süreç zamanla gündelik konuşma diline varıncaya kadar hayatın diğer alanlarında günümüze kadar devam etmiştir (Bk. Y1ld1z, 2006, 7-39).

Bu kısımda Yemen lehçesinde Türkçe ekler, Yemen lehçesinde Türkçe sözcükler, Yemen atasözleri ve deyimlerinde yer alan Türkçe sözcükler ve her iki toplumun atasözlerindeki ortak noktalardan hareketle Türkçenin Yemen lehçesi üzerindeki etkisi incelenmiştir. 


\subsection{Türkçe Ekler}

Başta Şam bölgesi (Suriye, Ürdün, Filistin, Lübnan) olmak üzere çoğu Arap lehçesinde Türkçe -cī, -lī, -lik, -siz yapım eklerinin sarf açısından farklı görevlerde kullanımına rastlamak mümkündür. Bu ekler arasında en yaygın olanı bireyin bir sanatla, nesneyle ilişkisini veya süregelen alışkanlıklarını ifade eden -ci yapım ekidir. Türkçe -ci yapım eki Arap lehçelerinde gerek kehrabcī/ كشكلجي (elektrikçi), maşkelcī/ (Sorun ç1karan kişi) gibi asl1 Arapça olan sözcüklerin (Alp, 2007, 214-215) gerek birincī/ ببقجي (Nargile çubuğu üreten kişi) gibi aslı Türkçe olan sözcüklerin (Esedî, 1987, 2/100-3/123) sonuna ilave edilmek suretiyle kullanılmaktadır. Örneklerde de görüldügü üzere bu ek Arap lehçelerinde Arap dilinin fonetik özelliklerine uygun olarak tüm sözcükler için -cī (جي) formunda medli/uzatmalı gelir. Türkçede olduğu gibi -ci, -c1, -cu, -cü, -çı, -çi, -çu şeklinde ses uyumuna uygun olarak gelmez. Ancak Irak lehçesinde -cī ekinin muhtemelen Farsçanın etkisiyle çoğunlukla -çī olarak geldiği görülür. Genel olarak Arap lehçelerinde kullanılan Türkçe ekleri şu şekilde örneklendirebiliriz:

-Cī eki: Afcī/ أثجي -avc1- (Esedî, 1987, 1/22); baltacī/ بلطجي -balta yapan kişi- (Esedî, 1987, 2/165); munāsebcī/ محاسبجي -muhasebeci- (Aytaç, 1994, 104); bāşmuhāsebcī/ باش محاسبجي -baş muhasebeci- (Aytaç, 1994, 41); bōyacī/ بويجي -boyac1- (Abduddâyim, 2006, 76; 'Allûb, 2014, 70);

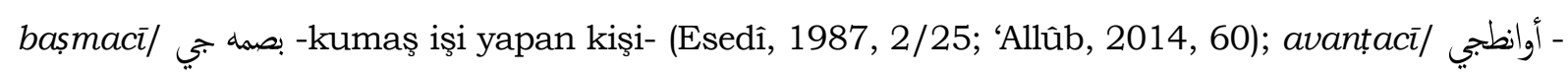
avantac1, otlakçı (Esedî, 1987, 1/466); borșacī/ بورصه جي -borsa işi yapan kimse- (Esedî, 1987, 2/193); birincī/ برنجي -birinci- (Esedî, 1987, 2/100); ikincī/ إكنجي -ikinci- ('Allûb, 2014, 34); cevhercī/ جوهرجي جزماجي -mücevher satan kimse- (Abdurrahim, 2012, 1/715); cizmāaì) satan kimse- ('Allûb, 2014, 89); cubukcī/ جبقجي -nargile çubuğu yapan kimse- (Esedî, 1987, 3/123); ezdecī/ ازدجي -eczac1- (Esedî, 1987, 1/10; 'Allûb, 2014, 24); kuzlikcī/ كزلكجي -gözlükçü(Esedî, 1987, 6/350); harbacī/ حربي -savaşçı kimse- (Abdurrahim, 2012, 1/741); hızmetcī/ -hizmetçi- (Abdurrahim, 2012, 1/847); kamyūncī/ قزمنجي حميونجي -kamyon sürücüsü- (Aytaç, 1994,

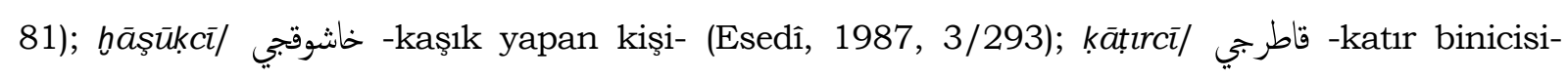
(Abdurrahim, 2012, 3/819); mkercī/ مكرجي -Kirac1- (Esedî, 1987, 7/184); kunduracī/ قندرجي köşker- (Esedî, 1987, 6/262); șābuvncī/ صابونجي -sabun satan kimse- (Abdurrahim, 2012, 2/1420); hāncī/ خانجي -hanc1- (Aytaç, 1994, 73); sufracī/ سفرجي -sofraya hizmet eden kişi(Abdurrahim, 2012, 2/1195); țūbcī/ طوبجي -top atış1 yapan asker- (Aytaç, 1994, 131); țornacī/ -tornac1- (Abduddâyim, 2006, 53); tenekcī/ تنكب طورني -tenekeci- (Abdurrahim, 2012, 1/628); yalancī/ يلنجي -yalancı dolma, et yerine içerisine yeşillik ilave edilen dolma- (Esedî, 1987, 7/443);

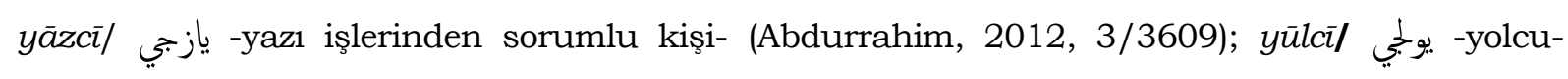
(Esedî, 1987, 7/454); tufekcī/ تفكجي -koruma; tüfek satan kimse- (Abdurrahim, 2012, 1/564; 
'Allûb, 2014, 79); bahşevāncī/ بخشوانجي -bahçivan- ('Allûb, 2014, 50); būstacī/ بوسطجي -postac1('Allûb, 2014, 57); taksecī/ كسجي -taksici- ('Allûb, 2014, 80); āşçî/ آثشيجي -yemek yapan kimse,

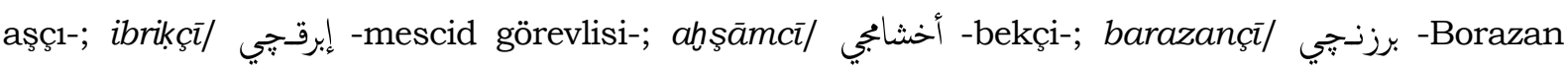

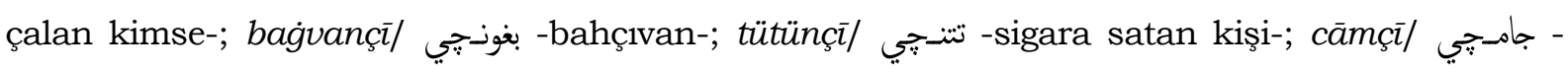
camc1, züccaciyeci-; ūtīcīl أوتيجي -ütü yapan kişi- (Mahfûz, 1964, 36); çādırçī/ جادرجي -çadır işi

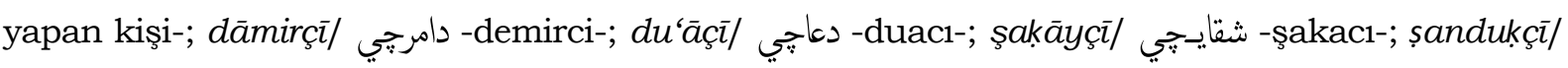

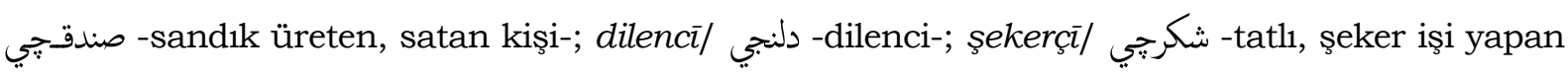

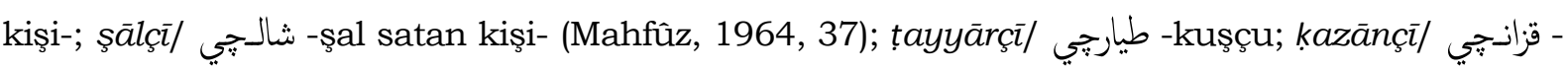

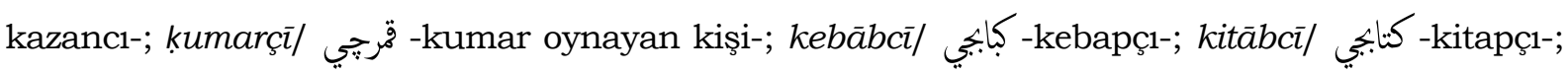
marmarcī/ مرمرجي-mermerci-; narkilleçī/ نزكيله -nargile satan kişi- (Mahfûz, 1964, 38-39).

-Lī eki: Burmālī/ بورمالي -burmalı bilezik- (Esedî, 1987, 2/194); cizmelī/ جزملي-çizmeli-; șārī cizmelī/ كزي جزمه -gizli(Abdurrahim, 2012, 3/2020); seferlī/ سَفَرْ لسفري -gezgin kişi- (Esedî, 1987, 2/194).

-Lik, -l1ḳ eki: Beylik/ بيلك -makam; devlete ait olan; askeri araç- (Aytaç, 1994, 44); çāmūrluk/ جامورلق -çamurluk- (Esedî, 1987, 3/121); kecelik/ كجه لك -gecelik- (Aytaç, 1994, 70); haremlik/ حرملك -haremlik- (Esedî, 1987, 3/192); selamlık/ سلاملك -selamllk- (Esedî, 1987, 4/192); sekatllk/ سَقَّقلق حفربرلك -sakatllk- (Esedî, 1987, 4/362); seferberlik/ -seferberlik(Abdurrahim, 2012, 2/1195); yaġmūrlik/ يغمورلك -yağmurluk- (Esedî, 1987, 7/449); kuzlik/ كزلك -gözlük- (Esedî, 1987, 6/350); bāşşlk/ باشلق -baş giyeceği- ('Allûb, 2014, 58).

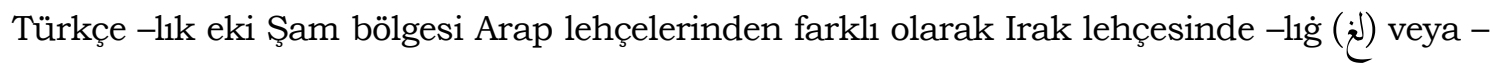

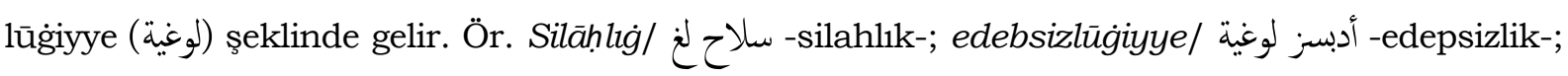
tenbellūgizyye/ تنبل لوغية -tembellik-; serserlūgiiyye/ سرسرلوغية فية -serserilik- (Mahfûz, 1964, 39).

-Sız, -siz eki: Bu ekin özellikle Irak lehçesinde daha yaygın kullanıldığı görülür. Ör. Bicimsiz/ بجمسيز -biçimsiz- (Esedî, 1987, 2/56); haksiz/ حقسز -haksız- (Aytaç, 1994, 72); ìmānsiz/

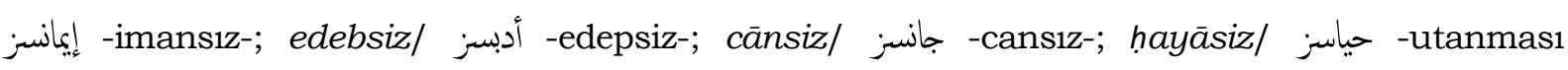
olmayan-; dimāg்siz/ دماغسز -beyinsiz-; 'aklsiz/ عقلسز -dini olmayan-;

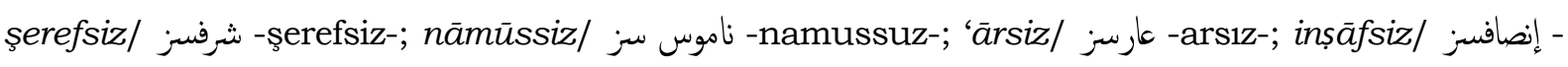
insafsız-; vicdānsiz/ وجدانسز -vicdansız-; terbiyyesiz/ تربيه سز سرون-terbiyesiz- (Mahfûz, 1964, 40).

Yemen lehçesinde de diğer Arap lehçelerinde olduğu gibi -cī eki kullanımı yaygındır. Ancak Suriye, Lübnan, Irak ve Mısır gibi diğer Arap lehçeleriyle kıyaslandığında Yemen lehçesinde Türkçe -cī eki kullanımı daha azdır. Ayrıca diğer Arap lehçelerinden farklı olarak -cī eki telaffuzda bazen -ş sesine dönüşebilmektedir. Ör. Nubetşī/ نبتشي -Nöbetçi, bekçi.

$\mathrm{Bu}$ hususa değinmişken Yemen lehçesinde Türkçe kelimelerin kullanımında meydana gelen ses değişimlerine de kısaca değinmekte fayda vardır. Lehçede $\mathbf{c}>$ ş dönüşümünün yanı 
sıra Arapçada kullanılmayan Türkçe p ve ç sessizlerine karşıllk olarak b (الباء), ş (الشين) ve c (الجيم) sessizleri kullanılır. Benzer durum diğer Arap lehçeleri için de geçerlidir. Ör.

p > b : ببخانه (Cebehāne); perde, بردي جـ بردات (Birdī); pervaz, برواز (Birvāz); piyade, بيادة (Biyāde); potin, بوتي، بوتن (Būtī, būtin); pul, بوله (Būle).

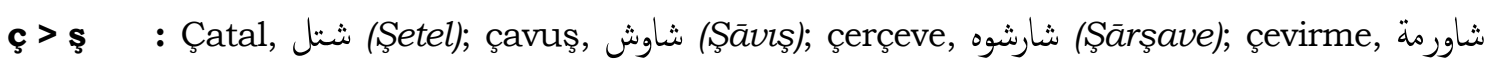

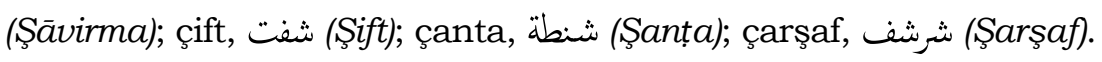

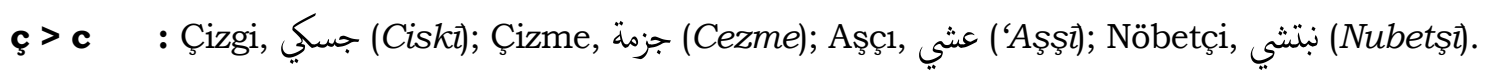

Türkçe kelime -u, -ü, -1, -i sesli harfleriyle sona eriyorsa Yemen lehçesinde bu ses genelde -ī sesine dönüşür. Ör.

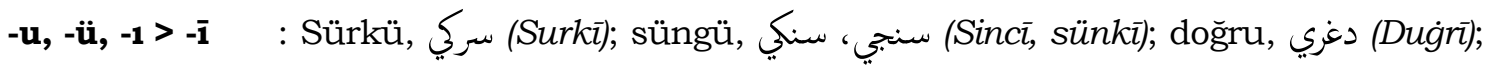
havlu, حولي (Haviī); kuzu, قوزي (Kūzi)); tepsi, تبري (Tibsî); terzi, ترزي (Tarzī).

Yemen lehçesinde tespit ettiğimiz -ci yapım eki alan sözcükler şunlardır:

Türkçe kelimeye eklenen -cī: 'Aşşī/ عشي -Aşç1- (Ekva', 1985, 55); Baltacī/ بلطجي -işsiz, serseri kimse- (Sûsuva, 2013, 55); Nubetşī/ نبتشي أوضه -nöbetçi, bekçi- (Ekva', 1985, 55); Avzacīl -oda görevlisi, hizmetlisi- (Ekva', 1985, 50); Tubşī/ طبي -topçu, top mermisi atan asker(Ekva', 1985, 53); Tifeşkīl تفشقي -tüfek yapan, satan ve kullanan kimse- (Ekva', 1985, 51); Avanțacī/ أونطجي-dolandırıc1; bedavac1- (Sûsuva, 2013, 55).

Arapça kelimeye eklenen -cī: Melbecī/ ملبجي -dayakçı, tokatç1; başkalarına şiddet uygulayan kimse-; mekvecī/ مكوجي -ütücü-; kahvecī/ قهوجي -kahve pişiren veya satan kimse-;

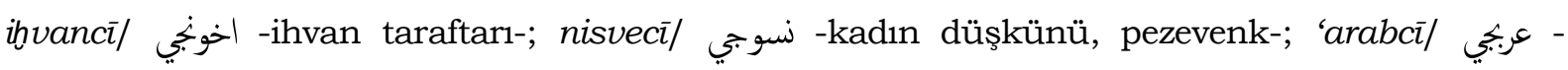
arabac1-; țubbacī/ طبجي -Assırı kilolu kimse- (K1, K2, K3, K4, K5).

Yemen lehçesinde Türkçe -sız, siz ekinin kullanımına rastlayamadık. Ayrıca Türkçe -li, lik eklerinin de kullanımının yaygın olmadığını söyleyebiliriz. Tespit edebildiğimiz örnek kelimeler şu şekildedir:

-li eki: Beşlì)/ بشلي -beşli, tüfek- (Sûsuva, 2013, 52); taṭlì/ تطلي suyun tatlı olmas1 (Ekva', $1985,51)$.

-11k eki: Selāmlik/ سلام لك -karşılama yeri- (Ekva', 1985, 53).

Yemen lehçesinde Türkçe -lik eki kullanımına örnek olarak 'silahlık' sözcügünü de verebilirdik. Ancak lehçede -lik eki yerine Türkçede de yaygın olarak kullanılan Farsça 'b̧ane' tamlaması tercih edilmiştir. Ör. Selehāne/ سلخاروت -silahlık- (Sûsuva, 2013, 69); Bārūthāne/ خانه -baruthane- (Ekva', 1985, 50); cebehāne/ جبخانه -cephane- (Sûsuva, 2013, 60).

\subsection{Türkçe Sözcükler}


Bu kısımda Yemen lehçesinde kullanılan Türkçe kelimeler askeri tabirler, meslek adları, yeme-içme, hayvan ve bitki isimleri, giyim-kuşam, mekân isimleri, genel eşya isimleri, edatlarsıfatlar ve diğer sözcükler olmak üzere çeşitli kategorilere ayrilarak sunulmuştur. Bu sözcüklerin çoğu Türkçe, bir kısmı da Türkçe aracıllğıyla nakledildiği öngörülen Farsça ve bazı batı dillerine ait sözcüklerdir. Dolayısıyla bir dönem İmparatorluk dili olması sebebiyle Türkçe, kendi içerisinde kullanılan birçok Farsça ve batı dillerine ait sözcüğün Arapçaya transferinde adeta arac1 dil konumunda olmuştur.

Yemen lehçesine dahîl olan Türkçe kelimeler incelendiğinde en fazla kelime alışverişinin askeri alanda gerçekleşmiş olduğunu söylenebiliriz. Bunu sırasıyla idareye dair tabirler, ev eşyası, alet-edevat, giyim-kuşam, yeme-içme sözcükleri takip eder. Yemen'de olduğu gibi diğer Arap lehçelerinde de kullanılan Türkçe sözcüklerde ilk sırada askeri tabirler yer alır. Bu durum Osmanlı'nın özellikle askeri, siyasi ve idari teşkilatlanmada oldukça ileri olmasıyla yakından ilgilidir. Nitekim toplumlar uzmanı olmadığı konularda, yani yeni durumlarda veya ihtiyaç hâsıl olduğunda ya yeni kelime türetir ya da kelime türetmek yerine onu diğer dillerden hazır olarak alır.

\subsubsection{Askerlikle İlgili Tabirler}

Türkçe askerlik tabirleri askeri birlikler, rütbeler; askeri malzemeler ve askeri meskenlergörevler olmak üzere üç grupta toplanmıştır.

Askerî birlikler, rütbeler: شاوش (Şāvış) çavuş, askerin başındaki kimse (Sûsuva, 2013, 70); باشا (Bāşā) paşa (K1, K2, K3, K4, K5); أمير آلآي (Emìr ālāy) tuğgeneral (Ekva', 1985, 50); عردي

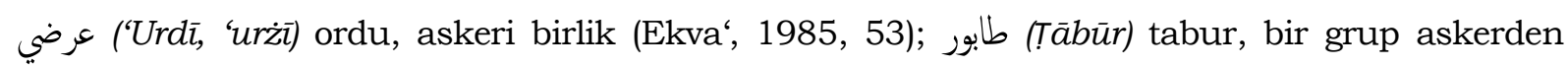
oluşan askeri birlik (Ekva‘, 1985, 53; Sûsuva, 2013, 76); بلوك ، بلك طعelūk, bülük) bölük, 100-160 askerden oluşan askeri topluluk (Ekva', 1985, 51; Sûsuva, 2013, 56); بيادة (Biyāde) yaya asker (Ekva‘, 1985, 51; Sûsuva, 2013, 58); سواري جـ سوارية (Sivārī ç. Sivāriyye) atlı birlikler (Ekva‘, 1985, 53; Sûsuva, 2013, 70); طبشي (Tubşī) topçu, orduda topçu birliğinde görev yapan asker (Ekva،, 1985, 53); تفشتي (Trfeşkī) tüfek yapan kimse, muharebe eri (Ekva', 1985, 51); جندرمة (Canderma) jandarma, askeri grup (Ekva', 1985, 52); ضابط ج ضباط (żābıt ç. żabāt) komutan (Ekva', 1985, 53); ياور (Yâver) yardımc1; devlet başkanı, komutan gibi yüksek rütbeli kimselerin komutlarını yazmak, gerektiğinde yerine ulaştırmakla görevli subay, emir subayı. (Ekva', 1985, 55).

Askerî malzemeler: باروت (Bārūt) barut (Sûsuva, 2013, 50); بشلي (Beşlī) beşli (bir tüfek çeşidi) (Sûsuva, 2013, 52); فشق (Faşak) fişek (Silah için) (Sûsuva, 2013, 80); بوتي بوتي (Būtī, būtin)

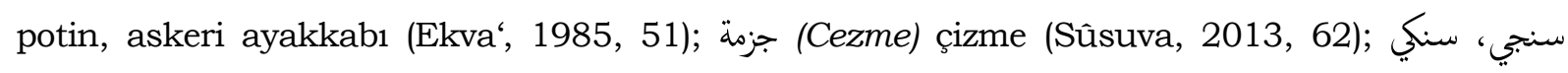
(Sincī, sünkī) süngü (Ekva', 1985, 53; Sûsuva, 2013, 69); طوب (Ṭūb) top mermisi (Ekva‘, 1985, 53); بورزان (Bevrazān) borazan (Ekva', 1985, 51; Sûsuva, 2013, 57); دانة (Dāne) top mermisi (Ekva‘, 1985, 52; Sûsuva, 2013, 64); قروزانة (Karavāne) asker yemeği dağıtılan büyük kap (Ekva‘, 1985, 54; Sûsuva, 2013, 82); ياي (Yãy) yay, ok yayı (Sûsuva, 2013, 95). 
Askerî meskenler ve görevler: باروت خانه (Bārūthāni) silahlar için barut üretilen yer (Ekva،, 1985, 50); جبخانه (Cebehāne) cephane (Sûsuva, 2013, 60); سلخانة (Selehāne) silahlık, silahların toplandiğ1 yer (Sûsuva, 2013, 69); كرون (Karakūn) karakol (Ekva‘, 1980, 152); قشلة (Kaşla) kışla (Ekva‘, 1985, 54; Sûsuva, 2013, 83); قاووش (Kāvūş) koğuş, askerin barınma yeri (Ekva‘, 1980, 152); عيك ('Ayak) adım (askeriye) (Ekva', 1985, 54); بلوك أمين (Belūk emin) bölükte yazı işlerinden sorumlu kişi (Ekva', 1985, 51); برابر ، بربر (Barābar, berber) birlikte; askeri yürüyüşler için (Ekva', 1985, 50); أفندم (Efendim) efendim; askerlerin komutana 'Emirlerinize hazırım' anlamında söylediği söz (Ekva', 1985, 50; Sûsuva, 2013, 48); سنجي تاك (Sincī tāk) Bir çeşit askeri emir'tüfeğin süngüsünü tak', (Ekva', 1985, 53).

\subsubsection{Meslek Adlar1}

عشي ('Aşşī) aşçı (Ekva', 1985, 54); بلطجي (Balțacī) mafya veya zorbalıkla geçinen işsiz kimse (Sûsuva, 2013, 55); باشثمهندس (Bāşmuhendis) başmühendis, en yetkili mühendis (Sûsuva, 2013, 51); خوجه (Hūca) ilkokul öğretmeni (Ekva', 1985, 52); قائم مقام (Kāim makām) orduda albay, yetkili kişi (Ekva،, 1985, 54); نبتشي (Nubetşī) nöbetçi, bekçi (Ekva', 1985, 55); أوضه جي (Avzacī) oda hizmetlisi (Ekva', 1985, 50); طبشي (Tubşī) topçu, orduda top mermisi atan asker (Ekva،, 1985, 53); تفشقي (Trfeşski) tüfek yapan kimse (Ekva‘, 1985, 51); ياور (Yãver) yardımc1 (Ekva،, 1985, 55); أونطجي (Avanțacī) dolandırıcilık yapan kimse (Sûsuva, 2013, 50); ترزي (Tarzī) terzi (Ekva', 1985, 51); حكيم (Hakim) hekim, doktor; قرصان ج قراصين (Kurșān ç. karāsinn) korsan, deniz hırsız1 (K1, K2, K3, $\mathrm{K} 4, \mathrm{~K} 5)$.

\subsubsection{Yeme-İçme}

بقاوة بوريك (Baklāva) baklava (Ekva', 1985, 51); بوريك (Sörek (Sûsuva, 2013, 58); (Şāvirma) döner (Sûsuva, 2013, 70); شربة (SSurba) çorba (Sûsuva, 2013, 72); طلمة (Tulma) dolma, et yerine sebzeyle yapılan dolma (Ekva', 1985, 53); خشاف (Huşãf) hoşaf (Ekva', 1985, 52); قطايف (Kațāyef) kadayıf tatlısı (Ekva', 1985, 54); كنافة (Künāfe) künefe (Ekva‘, 1985, 55); أصمان (Usmallī) siyah çay (Ekva‘, 1985, 54); بالوزه (Bālūze) muhallebiye benzer tatlı (Ekva', 1985, 50); صلصة (Salsa) salça (Sûsuva, 2013, 75); تطلي (Tațlī) tatlı (Ekva‘, 1985, 51); تنز (Tütun) sigara (Ekva', 1985, 51; Sûsuva, 2013, 59); ياغورت، يرت (Yāg̉ūrt, yurt) yoğurt (Ekva', 1985, 55; Sûsuva, 2013, 95); قوزي (Kūzī) Kuzu, kuzu çevirme (Ekva‘, 1985, 54; Sûsuva, 2013, 87); راحة حلقوم (rāḥa halkūm) lokum yapilışında kokulu su kullanıldığından terkibin başında راحة koku kelimesi gelir- (Sûsuva, 2013,

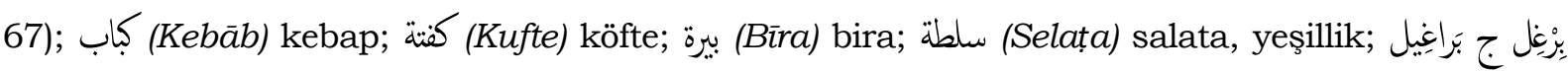

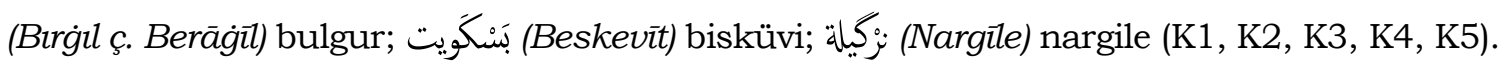

\subsubsection{Giyim Kuşam}


بصمة (Bașma) kumaş türü (Ekva', 1985, 51); بشمق ج بشامق (Başmak ç. başāmik) ayakkab1, sandalet (Ekva‘, 1985, 51; Sûsuva, 2013, 52); بليزق ، بليزق (Bileyzik, belizik) bilezik (Ekva', 1985, 51; Sûsuva, 2013, 57); فستنان (Fustān) uzun kadın elbisesi (Sûsuva, 2013, 79); قملك، كمليك (Kumlik, kumleyk) gömlek (Ekva', 1985, 54; Sûsuva, 2013, 89); كبك (Kelbek) kalpak, şapka (Ekva', 1985, 55; Sûsuva, 2013, 84); كندرة، قنطرة (Kündura, kunțura) kundura (Sûsuva, 2013, 86); كك (Kerk) kürk, deri ceket (Ekva‘, 1985, 55); مسد (Mesd) mest, ayakkab1 deri (Ekva‘, 1980, 153; Sûsuva, 2013, 92); ياقة (Yāka) gömlek yakası (Sûsuva, 2013, 95); يلق (Yelak) yelek (Ekva', 1985, 55); قاوق (Kāvuk) kavuk, şapka (Ekva‘, 1985, 54; Sûsuva, 2013, 81); الياشيلق (el-Yāşmāk) yalnızca gözleri açı1kta bırakan yüz örtüsü, yaşmak (Ekva‘, 1985, 58); شبشب جـ شباشب (Şibşib ç. Şebāş̧ib) şıpıdık, Şipşıp, plastik-ökçesiz terlik (Sûsuva, 2013, 72); كتيلة (Kurteyla) kurdela (Sûsuva, 2013, 88); جاكيب (Cākit) ceket; أنك (Etekk) etek, elbisenin at ucu; بابوج (Bābūc) pabuç; بالطو (Bâlttū) palto; (K1, K2, K3, K4, K5).

\subsubsection{Hayvan ve Bitki İsimleri}

بزاليا (Bezālyā) bezelye (Sûsuva, 2013, 52); اسبنك (İsbanak) 1spanak (Ekva‘, 1985, 50); لهانك (Lahāne) lahana (Sûsuva, 2013, 91); بيبار (Biybār, biysār) yeşil biber (Ekva‘, 1985, 51); دانة (Dāne) arpa, buğday tohumu (Ekva‘, 1985, 52; Sûsuva, 2013, 64); بامه (Bāmi) bamya; فاصويَّة (Fẫliyye) fasulye (K1, K2, K3, K4, K5); قرد (Kurd) kurt (Ekva‘, 1985, 54); قوزي (Küzī) kuzu, küçük koyun (Ekva', 1985, 54; Sûsuva, 2013, 87); جيلان (Ceylān) ceylan (K1, K2, K3, K4, K5).

\subsubsection{Eşya İsimleri}

(Bardāk) bardak (Ekva‘, 1985, 50; Sûsuva, 2013, 52); برداق (Bayrak) bayrak (Ekva‘,

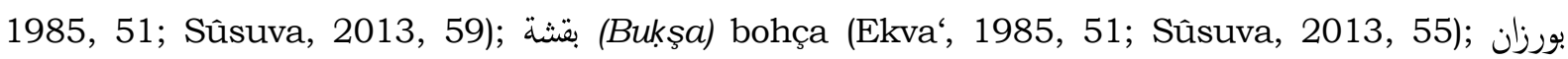
(Beurazān) borazan (Ekva', 1985, 51; Sûsuva, 2013, 57); بويه (Būya) boya, vernik ayakkabı için (Sûsuva, 2013, 58); جزوة (Cezva) cezve (Ekva', 1985, 51; Sûsuva, 2013, 63); شنطة (Şanța) çanta (Ekva', 1985, 53; Sûsuva, 2013, 74); شرشف (Şarşaf) kadının evden çıkarken giydiği siyah giysi (Ekva', 1985, 53; Sûsuva, 2013, 72); شتل (Şetel) çatal (Ekva', 1985, 53); شارشوه (Şārşave) çerçeve (Ekva‘, 1985, 53); شراب (Şerāb) çorap (Ekva‘, 1985, 53); شواله (Şuvāle) çuval (Sûsuva, 2013, 74); دمجانة (Damacāni) damacana, büyük su kabı (Ekva‘, 1985, 52); دربكة (Derabukke) darbuka (Sûsuva, 2013, 65); دولاب (Dūlāb) dolap (Sûsuva, 2013, 66); ألدونات (Eldivanât) eldiven (Ekva،, 1985, 50); (Firtike) filteke (Sûsuva, 2013, 79); حرنكة (Havlī) havlu (Sûsuva, 2013, 63); قامش (Kāmaş) kamç1; kamış (Ekva‘, 1985, 54; Sûsuva, 2013, 81); قروانة (Karavāne) lavabo; asker yemeği dağıtılan büyük kap (Ekva‘, 1985, 54; Sûsuva, 2013, 82); كيوله (Karyūla) karyola (Ekva‘, 1985, 55; Sûsuva, 2013, 88); كاصة (Kẫsa) kâse, kap (Ekva', 1985, 54); خاشوقة (Hāşūka) kaş1k (Ekva', 1985, 52); قايش 
(Kāâsss) kemer (Ekva', 1985, 54; Sûsuva, 2013, 81); خازوق (Hāzūk) kazık, mecazen kazık yeme (Sûsuva, 2013, 64); كاج (Kirbāc) kırbaç (Ekva', 1985, 54; Sûsuva, 2013, 88); كشبن (Kurşin) kurşun kalem (Ekva', 1985, 54); كريك (Kurayk) kürek (Sûsuva, 2013, 88); لكن، لجن (Leken, lecen) leğen, elbise yıkanılan büyük teşt (Ekva‘, 1985, 55; Sûsuva, 2013, 90); ماسة (Māse) masa (Ekva‘, 1985, 55; Sûsuva, 2013, 92); بردي جج بردات (Birdī ç. Beradāt) perde (Ekva', 1985, 50); بروانة (Bervāne)

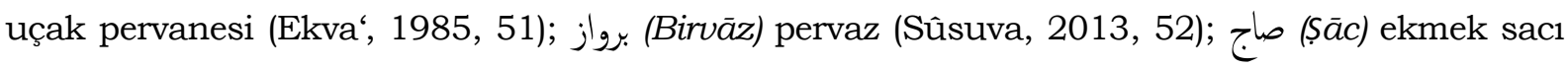
(Sûsuva, 2013, 74); سنجق، سنجاق (Sencak, sencāk) bayrak (Ekva', 1985, 53); سدوية (Sediyye) sedye

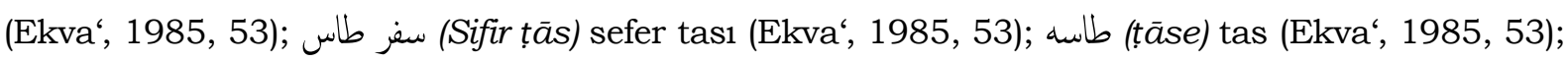
تخت (Taht) yatak (Ekva', 1985, 51); تخته (Tỉhta) tahta, yazı tahtas1 (Ekva', 1985, 51); طاون (Tâva) tava (Sûsuva, 2013, 77); طباشير (Ṭabāşir) tebeşir (Sûsuva, 2013, 78); تل (Tell) pencerelere haşere girmemesi için takılan tel (Sûsuva, 2013, 59); تنجرة (Tencera) tencere (Ekva', 1985, 51; Sûsuva, 2013, 60); تنكة (Teneke) teneke (Ekva', 1985, 51; Sûsuva, 2013, 60); تبسي جـ تباسي (Tibsī ç. Tebāsī) tepsi (Ekva‘, 1985, 52; Sûsuva, 2013, 59); طبة (Tabbe) futbol topu (Ekva‘, 1985, 53); يتقي (Yatak) yatak (Ekva', 1985, 55); يرقان (Yurkān) yorgan (Ekva‘, 1985, 55; Sûsuva, 2013, 96); باغة (Bāġa) sert plastik² (Sûsuva, 2013, 51); جردل (Cerdel) gerdel, kova3 (Sûsuva, 2013, 61); خرسانة (Harasāne) horasan ${ }^{4}$, ev yapımında kullanılan harç, çimento (Sûsuva, 2013, 64); دشيكات (Dişeykẫt) döşek, yer süngeri (Sûsuva, 2013, 65); بوري (Būrī) boru; فرشة (Firşa) firça; جنط (Cant) jant; كلبحة (Kilibçi) kelepçe; كنجة (Kemence) kemençe; كرجير (Kemer) kemerir) kevgir; لاستيك (Lāstîk) araç

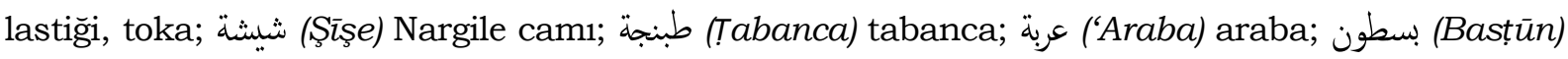
baston, asa; مكينة (Makkina) makine, mekanizma (K1, K2, K3, K4, K5).

İdareye dair eşya adları: دمغة (Damg்a) mühür, damga (Ekva', 1985, 52; Sûsuva, 2013, 66); بصمة (Basma) imza, mühür (Ekva', 1985, 51); أورنيك (Ornik) doktor raporu (Ekva', 1985, 50); بوله (Būle) posta pulu (Ekva', 1985, 51; Sûsuva, 2013, 58); رشته، رجته، رشده (Ruşite, recite, reşede) doktor reçetesi (Ekva', 1985, 52; Sûsuva, 2013, 67); نامونة (Nâmūne) numune, örnek (Ekva‘, 1985, 55); سركي (Surkī) görevli imza defteri (Ekva', 1985, 53; Sûsuva, 2013, 69); بردور (Burdūr)

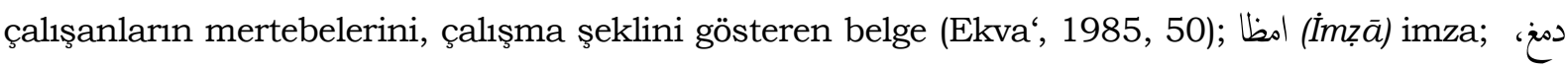

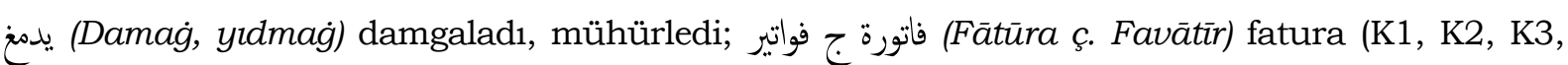
K4, K5).

\subsubsection{Mekân İsimleri}

\footnotetext{
2 Bağa sözcüğü eski Türkçede kaplumbağa veya deniz kaplumbağasının kabuğu anlamına gelir (Akalın vd., 2011, 225). Yemen lehçesinde kaplumbağa kabuğunun sertliğinden hareketle sert plastik malzemelere bāğa denmiştir.

3 Gerdel, Türkçede içerisine süt vb. şeyleri koymaya, hayvanlara yem vermeye yarayan kova biçiminde tahta veya deri kap anlamına gelir (Akalın vd., 2011, 932).

${ }^{4}$ Aslı Farsça hurāsān kelimesidir. Türkçede kiremit ve tuğla tozlarının kireç ve su ile karıştırılmasından elde edilen bir harç anlamında kullanılır (Akalın vd, 2011, 1109).
} 
بدروم (Bedrūm) bodrum, binanın en alt katı (Sûsuva, 2013, 51); بوغاز (Būg்āz) deniz geçidi, boğaz (Ekva', 1985, 51); فرن (Firn) firın (Ekva', 1985, 54); جمرك جـ جارك (Cumruk c. Cemārik) gümrük (Ekva‘, 1985, 52; Sûsuva, 2013, 63); خेخ (Hāne) yer, mekân (Ekva‘, 1985, 52; Sûsuva, 2013, 64); اسكله (İskile) iskele (Ekva‘, 1985, 50); كبري (Kūbrī) köprü (Ekva‘, 1985, 55); كوشة (Kūşe) gelin-damat kürsüsü (Sûsuva, 2013, 90); كثك (Küşk) tahtadan yapılmış oturak (Ekva‘, 1985, 55; Sûsuva, 2013, 89); لوكنده (Lūkende) otel (Ekva', 1985, 55); أوضه (Avza) oda (Ekva،, 1985, 50); رشدية (Raşdiyye) lise (Ekva', 1985, 52); سنجق ، سنجاق (Sencak, sencāk) sancak (kaza) (Ekva', 1985, 53); صلام لك صنف (Selāmlık) misafir karşıflama yeri okuldaki sinıf anlamında (Ekva‘, 1985, 53); تبة (Tebbe) tepe, dağın zirvesi (Ekva', 1985, 51); زنزانة (Zinzāne) zindan; küçük hücre (Sûsuva, 2013, 68); سفرة (Süfra) yemek sofras1; عبرة ('Ambar) ambar; بقزبه

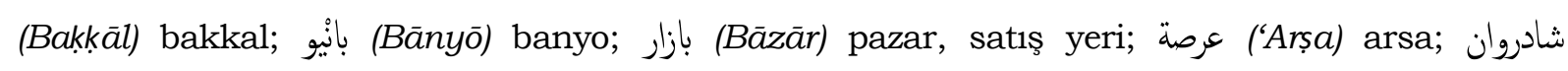
(Şādırvān) genel mekân ismi (K1, K2, K3, K4, K5)

\subsubsection{Yerleşim Yeri ve Kabile Adları}

Kabile Adları: Āli ibrik/ آل ابريق -Yemen Habbān bölgesinde yaşayan bir kabile- (Makahfí, 2002, 16); âli efendī/ آل أفندي -Yemen Mavr vadisinde yaşayan bir aile, aileye 'efendi' lakab1 Osmanlı döneminde verilmiştir- (Makahfî, 2002, 92); el-bārūdī/ البارودي Yemen Zabit şehrinde yaşayan bir kabile adı (Makahfî, 2002, 125); âli’l-bāşāa/ بلبت الباشا آلباش -Yemen Taiz şehrinde yaşayan ve soyları Ahmed b. Ali el-Mütevekkil'e dayanan aile adı, bu aile Yemen'de beytu'-Mütevekkil adılla da bilinir- (Makahfî, 2002, 126); âli bayrak/ آل بيرق-Yemen San'a şehrinde yaşayan bir aile ad1- (Makahfí, 2002, 209); āli ceylān/ آل جيلان -Yemen Sa'da bölgesinde yaşayan Haydān ailesinin bir kolu- (Makahfî, 2002, 381); āli dervīş/ آل درويش-Yemen Damt şehrinde yaşayan bir aile ad1- (Makahfì, 2002, 609); āli beuracī/ آل بورجي-Yemen Hudeyde şehrinde yaşayan bir aile ad1- (Makahfi, 2002, 203); āli'l-Celebī/ آل الجلبي -Yemen'de aile ad1(Makahfî, 2002, 342); خان (Hān) han, aile ismi (K1, K2, K3, K4, K5)

Yerleşim Yeri Adları: ḩāzūk/ خازوق -Yemen Hadramut yakınlarında bir kale- (Makahfí, 2002, 555); el-ḩān/ الخان -Yemen Cebel Râs bölgesinde idari merkez, ayrica Yarim bölgesinde bir mahalle ad1- (Makahfî, 2002, 557); zindānī/ ننداني -Yemen San'a şehrinde idari merkez- (Makahfí, 2002, 746); es-serāyā/ السرايا -Yemen’in Dâli‘ ilinin güneyindeki Melâh vadisinde yer alan dağlık bölgenin ad1- (Makahfî, 2002, 784); el-beyrak/ البيرك-Yemen Taiz şehri Maha bölgesinde yer alan bir yerleşim yeri ad1- (Makahfí, 2002, 209). el-Celebĩ/ الجلبي -Yemen Rucum bölgesinde idari merkez- (Makahfi, 2002, 342).

\subsubsection{Edatlar, Zarflar ve Sifatlar}


آب̂ا (Āblā) büyük kı kardeş, öğretmen (Ekva', 1985, 49; Sûsuva, 2013, 47); بابا (Bābā) baba; خانم (Hānım) hanım, eş (K1, K2, K3, K4, K5); أونطجي (Avanțacī) dolandırıc1 (Sûsuva, 2013, 50); دشان (Dışmān) düşman (Ekva‘, 1985, 52); دغري (Duġrī) doğru, sadık (Ekva‘, 1985, 52; Sûsuva, 2013, 66); أسكي (Eskī) eski (Ekva', 1985, 50); كهنة (Kühne) eski, köhne (Sûsuva, 2013, 88); رعريل (Razil) rezil (Ekva', 1985, 52); صاغ (Ṣāg்) sağ, diri, hayatta (Ekva', 1985, 53; Sûsuva, 2013, 74); بلش

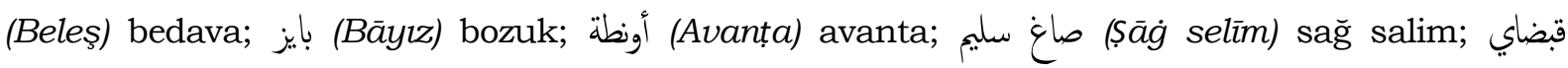
(Kabażāy) kabaday1, cesur (K1, K2, K3, K4, K5); تطلي (Taṭlī) suyun tatlı olmas1 (Ekva', 1985, 51); طز (Tuzz) Önemsiz, değersiz ${ }^{5}$ (Sûsuva, 2013, 78); طازâaze) taze (Ekva‘, 1980, 151); يلان (Yelān) yalan (Ekva‘, 1985, 56; Sûsuva, 2013, 97); يسق (Yasak) Yasak (Ekva', 1985, 55; Sûsuva, 2013, 96); باش (Bâş) baş, önde gelen; بوش (Būş) boş, kıymetsiz; دوز (Düz) düz, direk yön anlaminda; خام

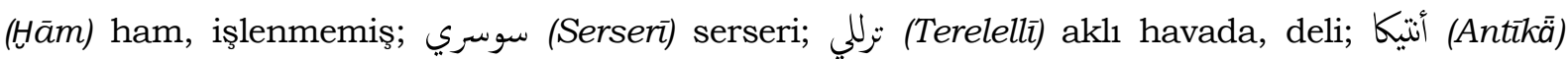
antika; سادة (Sāde) sade, katkısız; دستة (Deste) deste, onluk; درزينة (Derzine) düzine; (K1, K2, K3, K4, K5); كلك (Kẫki) hâkî renk (Sûsuva, 2013, 87); بلكي (Belkī) belki (Ekva،, 1985, 51; Sûsuva, 2013, 57); شندي (SSindī) şimdi (Ekva‘, 1985, 53); دغري (Duġrī) ön tarafa gitme, düz gitme, yön (Ekva،, 1985, 52; Sûsuva, 2013, 66); يوش يواش (Yevaş yevāş) yavaş yavaş (Ekva،, 1985, 56).

\subsubsection{Diğer Sözcükler}

آفرم (Āferim) tebrik anlaminda (Ekva', 1985, 49); عنقرية ('Ankariyye) angarya (Ekva', 1985, 54); عرض حال ('Arż hāal) şikâyet (Ekva', 1985, 53); عطش ('Ațaş) ateş (Ekva', 1985, 54); بخنشب (Bahşīş) bahşiş; بخش ايتمك (Bahş itmek) bahşiş verme (Ekva،, 1985, 50); شفت (Şift) çift, ikili olan (Ekva،, 1985, 53); شنكو (Şinkū) çinko (Ekva', 1985, 53); جسكي (Ciskī) çizgi (Ekva', 1985, 51); داقك (Dākiş) nakletme, tayin (Ekva', 1985, 52); هشلي، هشري (Hemşelī, hemşerī) ayn yurtta yaşayan kimseler

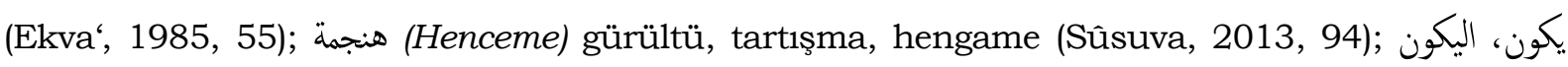
(Yekūn, el-yekūn) yekûn, toplam (Ekva', 1985, 55; Sûsuva, 2013, 49); يك (Yukk) yok (Ekva،, 1985, 55); خازوق (Hāzūk) kazık yeme (Sûsuva, 2013, 64); فيطوس (Fìtūùs) tatil, çalışma aras1; سبارش (Sebāriş) bir şeyin yapılmasını isteme, 1smarlama (Ekva‘, 1985, 57); طاقً الشاي (Tākam) takım, طاق çay takımı (Sûsuva, 2013, 77); باز ، بيوز (Bāz, ybavviz) bozuldu; جرجرج ، (Cercer, ycercir,

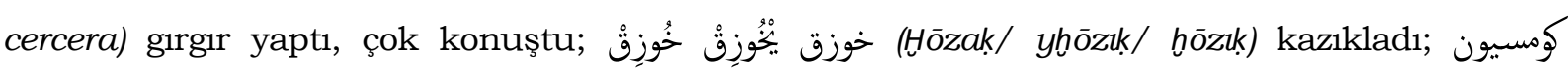
(Kūmisyōn) komisyon (K1, K2, K3, K4, K5).

\subsection{Yemen Atasözlerinde Türkçe Sözcükler}

Bütün toplumların belirli bir gerçeklik üzerine doğan ve nesilden nesile aktarılan atalarından kalmış sözleri/atasözleri vardır. Toplumun günlük yaşamında önemli yer tutan bu

\footnotetext{
5 Osmanlı'da tuz hariç diğer mallardan vergi alındığından Arap tüccarlar Osmanlı denetçilerine mallarının tuz olduğunu söylemiş ve vergi vermekten kaçınmıştır. Tuz önemsiz mal olarak görülmüş ve tuz kelimesi zamanla önemsiz, sıradan şeyler için sıfat olarak kullanılır olmuştur. Bk. (Esedî, 1987, 5/270)
} 
sözler bir milletin tarihini, estetik anlayışını, değerlerini, düşünce yapısını, duygu birikimini ve topluma dair diğer birçok şeyi açıklığa kavuşturur. Bu bakımdan bir toplumun toplumsal ve kültürel anlamda ne türden değişimler yaşadığı ve toplumun toplumsal ve kültürel anlamda günümüzde ne konumda olduğu araştırılmak istenirse başvurulacak temel kaynaklardan biri atasözleri olmalıdır (Ahmed, 2004, 51; Dilçin, 2000, 16).

Atasözleri her ulusun dilinde farklı adlarla anılır. Araplar; "atasözü" karşılığı olarak çoğulu emsāal olan mesel sözcügünü kullanırlar. Arap dilinde mesel kavramı sözlükte "bir şeye benzemek, bir şeyin benzeri olmak" anlamına gelir. Mesel kavramı yaygin olan "bir şeye benzemek" anlamının yanı sıra sözlükte "sıfat-vasıf, öğüt, kıssa, ders, örnek alınan, ayakta dikilmek, faziletli olmak" manalarına da gelir (Ezherī, 2001, 4/3340-3342).

Kelime anlamından anlaşılacağı üzere atasözlerinin temelinde benzetme yer alır. Atasözleri gündelik yaşantıda karşılaştığımız birtakım hadiselerin geçmişte yaşanan hadiselere benzetilmesi üzerine söylenir. $\mathrm{Bu}$ bakımdan benzer sosyal şartlar içerisinde yaşayan toplumlarda benzer atasözlerinin meydana geldiği görülebilir. Aslında bu sözler aynı fikirlerin aynı buluşların ayrı ayrı dillerde ifadesidir (Oy, 1972, 67). Doğan Aksan Her Yönüyle Dil-Ana Çizgileriyle Dilbilim adlı eserinde konuyu şu şekilde özetler:

"Atasözlerinin bir bölümü de dolaşıcı sözcüklerde olduğu gibi, bir ülkeden çıkmış, çeşitli ülkelere, dillere yayılmıştır. Pek çok atasözünün tıpkı kimi masallar gibi doğudan (Hint-İran ve Arap dünyası) alınarak Avrupa'ya yayıldığı anlaşılmaktadır.

Öte yandan komşuluk ilişkileri ve kültür akrabalığı nedeniyle atasözlerinin bir dilden ötekine aktarılması da çok sık görülen olaylardandır... Birçok dilde birbirine eş ya da yakın biçimde yaşayan atasözlerinin ilk kez hangi dilde kullanıldığının, hangi dilden alındığının kestirilmesi güçtür.” (Aksan, 2009, 3/39).

Araştırmamızda Yemen atasözleri Türk atasözleriyle ortak benzetmelere sahip olanlar ve ortak benzetmeye sahip olmayıp sadece Türkçe kelime ihtiva edenler olmak üzere iki kısımda ele alınmıştır. Atasözlerine dair vermiş olduğumuz bu ön bilgiden de anlaşlacağ üzere benzetme yönü ortak olan atasözlerinin ilk kez hangi dilde kullanıldığını kestirmek güç olduğundan bu atasözleri Türkçenin Yemen atasözlerine etkisi bağlamında ele alınmamıştır. Ancak örnek teşkil etmesi açısından çalışmada, Türkçe ve Yemen Arapçasında benzer bazı atasözleri örneklerine değinilmiştir.

\subsubsection{Ortak Benzetmelere Sahip Atasözleri}

Türkçe ve Yemen Arapçasından aynı benzetmelerin kullanıldığı atasözlerine ve deyimlere örnek olarak şunları verebiliriz:

1) 'Aduvv 'ākil hayrun min șadikk cahil/ عدو عاقل خير من صديق جاهل Akılllı düşman deli dosttan daha hayırlıdır (Ekva', 2/701). Türkçedeki 'Deli dostun olacağına akıllı düşmanın olsun' atasözüyle benzerdir. 2) 'İlm bilā 'amel ke-şecer bilā șemer/ علم بلا عمل كثنجر بلا ثمر Amelsiz ilim meyvesiz ağaç gibidir (Ekva‘, 1984, 2/725). 3) el-'užr akbbah mine’l-fíl/ العُخر أقبح من الفعل Özrü fiilinden beter. Türkçemizdeki 'özrü kabahatinden büyük' deyimiyle aynı anlamdadır (Ekva‘, 
1984, 2/702). 4) Kad sekațat min 'aynī/ قد سقطت من عيني/ Gözümden düştü (Ekva', 1984, 2/798). 5) Kill vāhid yirca' li-aṣlih/ كل واحد يرجع لأصله Her şey aslına rücu eder (Ekva', 1984, 2/865). 6) Kul lī men asdikāek ekul lek men ente/ قل لي من أصدقاءك أقل لك من أنت مana arkadaşını söyle sana kim olduğunu söyleyeyim (Ekva', 1984, 2/819). 7) Mecnūn yermì hacra li'l-bìr ve erba'ūn 'ākil yı'cazū

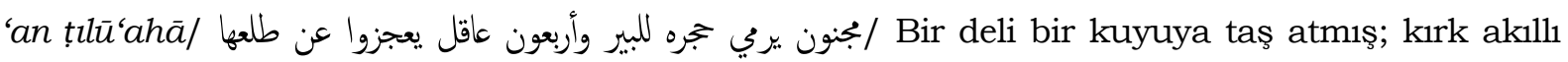
çıاkaramamış ('Anān, 1983, 31). 8) Men 'allemenī harfen șirtu llu 'abden/ من علمني حرفا صرت له عبدا Bana bir harf öğretenin kölesi olurum (Ekva', 1984, 2/1251). 9) Men ġāb mine’l-‘ayn ġāb mine’lhătı̂r/ Gözden uzak olan zihinden (gönülden) de uzak olur (Ekva', 1984, 2/1254). 10) el-Cār kable'd-dār/ الجار قبل الدار من Komşu evden önce gelir, ev alma komşu al (Ekva', 1984, 1/358). 11) Hubbu'l-vațan mine'l-immān/ الإيمان / Vatan sevgisi imandandır (Ekva', 1984, 1/402).

\subsubsection{Türkçe Sözcük İhtiva Eden Atasözleri}

Türklerle İlgili Atasözleri: Mã biş selā ve’t-Turk fovk bak‘āa / ما بش سلا والتركك فوق بَقُع / Türkler yeryüzündeyken unutmak yok. Bu sözle Türkler Yemen'de hüküm sürdüğü müddetçe sıkıntıların unutulamayacağı ifade edilir. (Ekva', 1984, 2/1010). el-Yemen makbbrate'l-Etrāk/ الميمن مقبرة الأثراك / Yemen, Türklerin kabristanıdır (Ekva', 1984, 2/1384).

Türkçe kalıpların yer aldığı atasözleri: Kur’ān cūk īmān yūk/ قرآن جوك إيمان يوك / Çok Kuran okur; ama iman yok (Ekva‘, 1984, 2/805). Kalbī yhabbek velakin beş bara yūk dir/ قلبي يجبك ولكن بش بره يوك در Kalbim seni sever ama beş para yoktur (Ekva', 1984, 2/823).

Aferin-siktir: Milyūn āferin bi-vāhid sekter/ مليون آفرن بواحد سكتر/Bir kötülük milyon iyiliği unutturur (Ekva', 1984, II/1158).

Bohça, para6: Kill bukşa ti'rif mevlāhāa / اكل بقشة تعرف مولاها Para sahibini tanır. Bu atasözüyle harcanan emeğin zayi olmayacağına, kişinin mutlaka emeğinin karşılı̆̆ını göreceğine dikkat çekilir (Ekva‘, 1984, 2/848). Bukşa bāttıl/ بقشه باطل/ Para gelip geçicidir (Ekva‘, 1984, 1/291; 'Anān, 1983, 32).

Boru: Būri’ș-șubh mismāri'r-rukeb/بوري الصبح مسمار الركب/ Sabah sigaras1 eklemlere çividir. (Ekva', 1984, 1/299). Burada būrī kelimesi şekil benzerliğiyle alakalı olarak sigara anlamında kullanilmıştır.

Hengâme7: el-Henceme nıșf el-kuțāl/ الهنجمة نصف القتال/ Hengâme savaşın yarısıdır (Ekva', 1984, 2/1327).

Kaz1k: Küllā ḩāzūkih vațnih/ خلا خازوقه وطنه/ Her kazığın bir ölçüsü vardır. Yani her zorluk kişinin tahammül edebileceği ölçüdedir (Ekva', 1984, II/869). Men kậl lek ‘ūd kul lih ḩāzūk/ من قال (لك عود قل له خازوق Sana odun diyene sen kazık de. Yapılan iyiliğin ve kötülüğün altında kalınmaması gerektiği vurgulanır (Ekva', 1984, 2/1259; 'Anān, 1983, 28).

\footnotetext{
6 Aslı Farsça olup Yemen lehçesine Osmanlı Türkçesi vasıtasıyla geçen 'bukșa' sözcüğü, lehçede hem bohça hem de para anlamında kullanılır. Bu sözcüğün lehçede para anlamında kullanılması muhtemelen eskilerin paralarını mendile sararak saklamalarıyla ilgilidir.

7 Hengâme kelimesinin aslı Farsça olup Yemen lehçesine Osmanlı Türkçesi aracılı̆̆ıyla geçmiştir.
} 
Kek8: Gंunice'l-kebīr sā‘ kä‘k er-remād/ غنج الكبير ساع/متل ككك الرماد / Yaşlının cilvesi yenmeyen ve bir faydası da olmayan- kül keki gibidir (Ekva', 1984 2/756; 'Anān, 1983, 37).

Kumru9: Fāra fi mcirāb velā kumrī fi msehāāb/فاره في الجراب، ولا قري في امسحاب /Çoraptaki fare, havadaki kumrudan daha evladır (Ekva', 1984, 2/760).

Kurt: il-kurd fi 'ayn ammih ġazēl/ القرد في عين أمه غزال Kurt anasının gözünde ceylandır (Ekva', 1984, 2/808; 'Anān, 1983, 50).

Kuruş10: il-kurş el-ebyaż yinfa' fil-youmi'l-esved/ القرش الأبيض ينف في اليوم الأسود Bolluk zamanında artırılan para kara günde fayda sağlar (Ekva', 1984, 2/808). Kurş devvār velā elf havvār/ قرش دوار، ولا الف حوار / Harcanan para cüzdandakinden evladır. Aşırı para biriktirme hırs1 olan kimseler için kullanılır (Ekva', 1984, 2/808). il-Kurş 'abdek mā dām fi ceybek fein harac feente 'abdih/ القرش عبدك مادام في جيك فإن خرج فانت عبده Cebindeki para senin kulun, çıktığında ise sen onun kulu olursun (Ekva', 1984, 2/809). Kirş velā nihdeh/ قرش ولا نهده Para, pişmanliktan evladır. Bu sözle pişman olunmadığı müddetçe istenilen şeyi satın alma tavsiye edilir (Ekva', 1984, 2/809; 'Anān, 1983, 65). Men kubir kırşu 'alā șitu/ من كبر قرشه علا صينه Serveti artanın şöhreti de artar (Ekva', 1984, 2/1270).

Paşa: Vācib 'alā men 'ş̧ı yuthanan ve yiddiye'l-mā mine'l-bāşī/ واجب على من عشق يطحن ويدي الما من Âşsk olanın kuyudan su istemesi ve unu öğütmesi gerekir. Âş1k amacina ulaşma umuduyla tüm zahmetlere katlanır. Buradaki bāşī sözcüğüyle Osmanlı valisi Muhammed Ali Paşa'nın Yemen'de açtırmış olduğu kuyu kastedilir (Ekva', 1984, 2/1331).

Taka11: Mā ḳadd mara şahbit min țāka/ ما قَذْ مَره شخت من طاقه / Takadan idrar yapmak kadın işi değildir. Bu söz imkânsız işlerle uğraşan kimseler için söylenir (Ekva‘, 1984, 2/1061). Tubrıca mine'-bāb ve yırca“ mine'țțāka/ تخرجه من الباب ويرجع من الطاقة Kapıdan çıkar, pencereden girer (Ekva', 1984, 1/329). Hakka'n-nās fi'ț-țāka/ İnsanların hakkı pencerede. Yani adalet hizlıca yerini bulacak anlamında kullanılır (Ekva', 1984, 1/429).

Tas: Iżrnb eț-ṭāse tecīk miyt raḳāạa/ اضرب الطاسه تجيك مية رقاصة Tasa vur, sana yüz dansç1 getirir (Ekva', 1984, 1/182; 'Anān, 1983, 226). Bakarate'l-mizeyyin mā 'ad tıftıca' mine'țțāse/ بقرة المزين ما عد تنغجع من الطاسه Berberin ineği tastan korkmaz (Ekva', 1984, 1/289; 'Anān, 1983, 73). el-

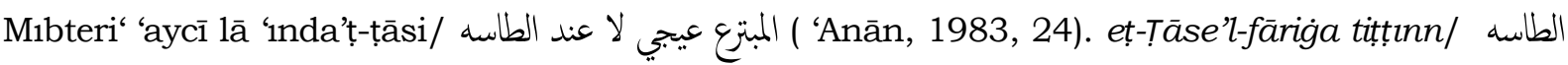
الفارغة تطن Boş tas çınlar, ses çıkarır (Ekva', 1984, 1/672).

Terlik, başmak: Vechukum ekber başmak/ وبحكى أكبر بشمق / Yüzünüz terlikten büyük. Bu söz çok basit bir işte başarısız olan kimseler için alay mahiyetinde kullanılır. Anlatıya göre kadın gurbete giden kocasından dönüşte kendisine terlik getirmesini ister. Fakat adam hanımına terlik almayı unutur. Koca hatasından dolayı özür diler; hanımı ise ona bu sözle karşılık verir

\footnotetext{
8 Kek kelimesinin aslı İngilizce 'cake' sözcügüdür. Katılımcılardan bir kısmı bu kelimenin Yemen Arapçasına Türkçe aracıllğıyla geçtiğini belirtmiştir (K2, K5).

9 Aslı Farsça olan 'kumrî’ kelimesi Yemen Arapçasına Osmanlı Türkçesi vasıtasıyla geçmiştir.

10 Kuruş kelimesinin aslı Almanca 'Groschen' sözcüğüdür. Türk lirasının yüzde biri değerinden paraya karşılık gelir (Akalın vd., 2011, 1539). Yemen Arapçasına Osmanlı Türkçesi aracıllğıyla geçmiștir.

11 Taka, tavana yakın kemerli küçük pencere anlamına gelen Türkçe kelimedir (Doğan, 1996, 1037).
} 
(Ekva', 1984, 2/1336). Başmak marati fi'l-beyt velā dlkn 'ammi fís-sūk/ بشمق مرتي في البيت ولا دقن عمي . Evde hanım terliği, çarşıda amca sözü dinlemez (Ekva', 1984, 1/280; Anān, 1983, 44).

Vapur-Tabur: eț-Ṭābūr ve şahnet bābūr/ الطابور وشحنة بابور Tabur ve bir vapur dolusu. Kalabalığı, izdihamı ifade etmek için kullanılır (Ekva', 1984, 1/682).

\section{Sonuç}

Anadolu'nun gerek tarihi gerek jeopolitik konumu gereği Arap diyarı olarak da bilinen Orta Doğu coğrafyasıyla sürekli bir bağlantısı olmuştur. Anadolu'nun Orta Doğu ile temasında yani Türk-Arap ilişkilerinde Türklerin İslamiyet’i kabulünden sonra gerçekleşmiş olan dinî birlik de önemli bir rol oynamıştır. Türk-Arap ilişkileri, Osmanlı'nın bir dönem Arap coğrafyasındaki hâkimiyeti ile de zirve noktasına ulaşmıştır. Diğer birçok Arap ülkeleri gibi bir dönem Osmanlı hâkimiyetine giren Yemen de bu etkileşime dâhil olmuş ve Türk-Yemen ilişkileri kültürün en önemli unsuru olan dil alanında da kaydedilmiştir. Türkçe sözcükler, Yemen Arapçasına ya doğrudan Osmanlı Türkçesi ya da başta Mısır Arapçası olmak üzere diğer Arap lehçeleri kanalıyla da dâhil olmuştur. Ayrıca bir dönem İmparatorluk dili olan Türkçe, birçok Farsça ve Batı dillerine ait sözcüğün Yemen ve diğer Arap lehçelerine transferinde aracı dil olmuştur. Araştırmamız neticesinde günümüz Yemen Arapçasında doğrudan Türkçe veya Türkçe vasıtasıyla girmiş 296 sözcüğün kullanıldığı görülmüştür.

Türkçenin, Yemen Arapçasına hem sözcük hem de yapı/Türkçe ekler bakımından etkisi de söz konudur. Türkçe ekler bağlamında Yemen Arapçasında, Şam bölgesi (Suriye, Ürdün, Filistin, Lübnan) Arap lehçelerinde de çokça kullanılan Türkçe -cī, -lī̄, -lik yapım eklerinin kullanıldığı görülmüştür. Ancak Yemen lehçesinde, Şam bölgesi Arap lehçelerinde kullanılan Türkçe -siz eki kullanımına rastlanılmamıştır.

Yemen Arapçasında kullanılan Türkçe sözcükler tasnif edildiğinde en fazla kelime aktarımının özellikle askerî ve idarî alanda gerçekleştiği görülür. Bunu sırasıyla ev essyası, aletedevat, giyim-kuşam, yeme-içme sözcükleri takip eder. Aslında Türkçe askeri ve idarî tabirlere diğer Arap lehçelerinde de sıkça rastlanır. Bu durum Osmanlı’nın özellikle askeri, siyasi ve idari teşkilatlanmada oldukça ileri seviyede olmasıyla yakından ilgilidir. Özellikle Yemen bölgesinde ortaya çıkan birçok isyan ve ayaklanmalara karşı Osmanlı Devletinin farklı zaman aralıklarında atamış olduğu vali ve farklı statüdeki memurlar ile bölgede asayişi sağlamak adına göndermiş olduğu askeri birliklerin ve dolayısıyla bölgede konuşlanan Türk nüfusun ciddi bir etkisinin olduğunu da söyleyebiliriz.

Türkçe-Yemen Arapçası etkileşimine yapı ve sözcük aktarımının gerçekleştiği günlük konuşma dilinin yanı sıra Yemen bölgesi yerleşim yerleri ve kabile adlarında, kalıp ifadelerinde/atasözlerinde de rastlanılmıştır. Nitekim bir sözcüğün diğer bir toplumun atasözlerinde dahi kendisine yer edinmesi, o sözcüğün ilgili toplum tarafından sıklıkla kullanıldığının ve benimsendiğinin en önemli göstergelerindendir. Bu durum her iki toplumun kültür ilgilerinin niteliğini ve sınırlarının genişliğini gözler önüne serer. 


\section{Kaynakça}

'Allūb, Abdulvehhāb. Mu'cemu'd-dahỉ fi'l-âmmiyyeti'l-Mıșriyye. Kahire: el- Merkezu'l-Ḳavmī li'tTercume, 2014.

'Anān, Zeyd b. Ali. el-Lehcetu'l-Yemāniyye fi'n-nuket ve'l-emsāali’ș-Șan'āniyye. Yemen: Yemen Archive, 1983.

Abduddāyim, Muhammed. el-Kelimātu't-Turkiyye fi kavāidi'l-luġati'l-'Arabiyye ve'l-lehceti'sSūriyye. Humus: yy, 2006.

Abdullah, Yusuf Muhammed. el-Mevsū'atu'l-Yemeniyye. San‘a: Müessetu'l-Afifi's-Sekāfiyye, 2003.

Abdurrahim, Yasin. Mavsu'atu'l-'āmmiyyeti’s-Sūriyye. 3 cilt. Dımeşk: Vizāratu's-Sekāfe, 2012.

Ahmed, İbrahim. eş-Şa‘bu'l-Mıșrī fì emsālihi'l-‘āmmiyyeh. Kahire: eş-Şeriketu'd-Devliyye li’tTibā‘a, 2004.

Akalın, Şükrü Haluk vd. Türkçe Sözlük. Ankara: Türk Dil Kurumu Yayınları, 2011.

Aksan, Doğan. Her Yönüyle Dil-Ana Çizgileriyle Dilbilim. 3 cilt. Ankara: Türk Dil Kurumu Yayınları, 2009.

Algül, Hüseyin. "Himyerîler", Türkiye Diyanet Vakfi İslâm Ansiklopedisi. 18/62-63. İstanbul: TDV Yayınları, 1998.

Alp, Musa. "Farklı İki Açıdan Arapça: Fusha ve Avamca". Çukurova Üniversitesi İlahiyat Fakültesi Dergisi 11/2 (2011), 87-110.

Alp, Musa. "Kelimelerin Göçü: Türkçe Nisbet Eki “-ci' nin” Şam Bölgesi (Suriye, Ürdün, Filistin ve Lübnan) Arap Halk Ağzında Kullanımı Hakkında Bir Araştırma”. Ç.Ü. Ilahiyat Fakültesi Dergisi $7 / 1$ (2007), 179-226.

Apak, Âdem. Ana Hatlariyla İslam Tarihi, İstanbul: Ensar Neşriyat, 2007.

Aydın, Mustafa. İk Dönem İslâm Toplumunun Şekillenişi. İstanbul: Yayınevi, 1991.

Aydın, Nurhan-Ergün, Elif. "Geçmişten Günümüze Yemen”, Yeni Türkiye 23/98 (2017), 5-27.

Aynî, Ebū Muhammed Bedreddīn Mahmūd b. Ahmed b. Musa el-Hanefi. 'Umdetu'l-ḳārī Şerḥu Sahīh el-Buhārī. Kahire-Beyrut: y.y., ts.

Aytaç, Bedrettin. Arap Lehçelerindeki Türkçe Kelimeler. İstanbul: Türk Dünyası Araştırmaları Vakfi, 1994.

Barlak, Yasemin. “Yemen'de Bir Osmanlı Şehri: San'a”. İSTEM (30) 2017, 333-354.

Barlak, Yasemin. Dinî ve Siyasî Yönden Osmanlı Devleti İdaresinde Yemen (1872-1909). Sansun: Ondokuz Mayıs Üniversitesi Sosyal Bilimler Enstitüsü, Doktora Tezi, 2013.

Barlak, Yasemin. Kabilecilik Anlayışının Hz. Ali Dönemi Siyasi Gelişmelerine Etkisi. Sansun: Ondokuz Mayıs Üniversitesi Sosyal Bilimler Enstitüsü, Yüksek Lisans Tezi, 2006.

Bostan, İdris. "Yemen", Türkiye Diyanet Vakfi İslâm Ansiklopedisi. 43/406-412. İstanbul: TDV Yayınları, 2013.

Coşkunoğlu, Cihangir. Yemen Vazat-Luhye Mintıka Kumandanlığı Harp Ceridesine Göre I. Dünya Savaşı ve Yemen Cephesi. Çankırı: Çankırı Karatekin Üniversitesi Sosyal Bilimler Enstitüsü, Yüksek Lisans Tezi, 2015.

Cuhen̄̄, Muhammed b. Feyz el-Hemdānī-Mahmud, Hasan Süleyman. es-Suleyhiyyūn ve'lHareketu'l-Fātimiyyûn fi'l-Yemen. San‘a: Menşūrātu'l-Medīne, 1986. 
Curafì, Kādī Abdullah b. Abdulkerīm, el-Muktețaf min Tārīhi'l-Yemen. Beyrut: Asru'l-Hadīs, 1987. Çağatay, Neşet. "Samîler-Araplar ve Güney Arabistan Devletleri”, AÜIFD 4/3 (1955), 44-67.

Çağatay, Neşet. İslâm'dan Önce Arap Tarihi ve Cahiliye Çağı, Ankara: AÜİFY, 1957.

Çağrıc1, Mustafa. "Fîl Sûresi", Türkiye Diyanet Vakfi İslâm Ansiklopedisi. 13/69-70. İstanbul: TDV Yayinları, 1996.

Demirci, Kadir. “İman da Hikmet de Yemendedir' Hadisine Dair Bir İnceleme”. Dini Araştırmalar 14/38 (2011), 95-122.

Dilçin, Dehri. Edebiyatımızda Atasözleri. Ankara: Türk Dil Kurumu Yayınları, 2000.

Doğan, Mehmet. Büyük Türkçe Sözlük. 11. Baskı. b.y.: İz Yayıncılık, 1996.

Döner, Ertuğrul. "Dine İlişkin Bazı Bilgi, Rivayet ve Kıssaların Hareket Noktası: Yemen/Yemen Yahudi ve Hıristiyanları". Dinî Araştırmalar 18/16 (2014), 209-232.

Ekva', İsmail b. Ali. "Kelimāt Turkiyye fi'l-lehecāti'l-Yemāniyye”. Mecma'u'l-'Tmì̄ 'Irākī 3 (1980), 145-154.

Ekva', İsmail b. Ali. "Kelimāt Turkiyye musta'mele fi'l-Yemen". Eklîl (1985), 49-58.

Ekva', İsmail b. Ali. el-Ems̄ālu’t-Yemāniyye. 2 cilt. Beyrut: Muessesetu'r-Risāle, 1984.

Eroğlu, Muhammed. "Ashâbü1-Uhdûd", Türkiye Diyanet Vakfi İslầm Ansiklopedisi. 3/471. İstanbul: TDV Yayınları, 1991.

Esedīi, Muhammed Hayruddîn. Meusū'atu Haleb el-mukārane. 7 cilt. Halep: Cem 'iyyetu'l-'Ādiyāt, 1987.

Ezherī, Ebū Manșūr Muhammed b. Aḥmed. Tehzỉbu'l-lug̉a. thk. Riyāz Zekī Kạașım. 4 cilt. Beyrut: Dāru'l-Ma'rife, 2001.

Fayda, Mustafa. İslâmiyet'in Güney Arabistan'a Yayılışı. Ankara: Ankara Üniversitesi İlahiyat Fakültesi Yayınları, 1982.

Fıçıcı, Emine. "Osmanlı Şehitlerinin Efsane Diyarı Yemen Üzerine Notlar”. İslâm Ülkeleri Tarih ve Coğrafya Etütleri 1 (2009).

Gökalp, Yusuf. "Yemen'de Zeydi-Sünni İlisskilerinin Tarihi Arka Planı", e-Makâlât Mezhep Araşttrmalan 6/2 (2013), ss. 87-114.

Günel, Gökçe-Dişli, Gülşen. "Yemen'de Bir Osmanlı Eseri: Bekiriye Camii”. Ankara: Vakıflar Genel Müdürlüğü Yayınlan, 2011.

Haidari, Khulod. Türk Halk Edebiyatında Yemen. Samsun: Ondokuz Mayıs Üniversitesi Sosyal Bilimler Enstitüsü, Yüksek Lisans Tezi, 2016.

Halil Kurt, "Yemen", Türkiye Diyanet Vakfi İslâm Ansiklopedisi. 43/400-401. İstanbul: TDV Yayınları, 2013.

Hamdānī, Ebū Muhammed Hasen b. Ahmed. Șıfatu Cezīrati'l-'Arab. thk. Muhammed b. Ali elEkva. San‘a: Mektebetu'l-İrşād, 1990.

Hatipoğlu, Turgut. Yemen'in Osmanlı'dan Ayrllşsı (Kopuşu). Ankara: Gazi Üniversitesi Sosyal Bilimler Enstitüsü, Yüksek Lisans Tezi, 2004.

Hitti, Philip. Siyasi ve Kültürel İslâm Tarihi. çev. Salih Tuğ. İstanbul: MÜİFY, 2011.

Hizmetli, Sabri. İslam Tarihi. Ankara: AÜİFY, 1991.

İbn Manzūr, Ebül-Fazl Cemâlüddîn Muhammed b. Mükerrem. Lisānu'l-'Arab. thk. Abdullah Ali el-Kebîr vd. Kahire: Dâru'l-Meârif, trs.

İhsan Süreyya Sirma, "Yemen", İslam Ansiklopedisi. 13/371. İstanbul 1993.

İryānī, Mathar Ali. el-Mu'cemu'l-Yemenī fi'tlug̉a ve't-terās̄. Dimeşk: Dāru'l-Fikr, 1996.

Kadri, Hasan. Yemen ve Hayatı, İstanbul: Dersaadet, 1910. 
Kazanc1, Ahmet Lütfi. "Ebrehe”, Türkiye Diyanet Vakfi İslâm Ansiklopedisi. 10/79-80. İstanbul: TDV Yayınları, 1994.

Kurt, Abdurrahman. "Sosyo-Ekonomik ve Kültürel Yönden İslam Öncesi Mekke Toplumu". UÜIFD 10/2 (2001), 97-122.

Mahfūz, Hüseyin Ali. "el-Elfāżu't-Turkiyye fill-lehecāti'l-'Irāḳıyye”. Mecelletu't-Turās̄i'ş-Şa'bī 6 (Bağdat 1964), 33-57.

Maḳaḥi, İbrahim b. Ahmed. Mu'cemu'l-büldān ve'l-kabāili'l-yemeniyye. Yemen: Dāru'l-Kelime, 2002.

Oy, Aydın. Tarih Boyunca Türk Atasözleri. İstanbul: Türkiye İş Bankası Kültür Yayınları, 1972.

Özbaran, Salih. "Osmanlı İmparatorluğu ve Hindistan Yolu: XVI. Yüzyıl Başında Hint Okyanusu". İstanbul Üniversitesi Edebiyat Fakültesi Tarih Dergisi 31 (1978), 65-146.

Playfair, Robert L. A History of Arabia Felix or Yemen. Byculla: Education Society's Press, 1859.

Porter, J.R. "Arabia Felix: Israelites, Jews and Christians". ed. Ian Richard Netton. Arabia and The Gulf: From Traditional Society to Modern States, London 1986.

Sarı, İsa. "Dil Etkileşimi Bağlamında Ses-Anlam Eşlemesi ve Türkçedeki Örnekleri", Türk Kültürü 1 (2013), 1-27.

Seydişehri, Mahmud Esad. İslâm Tarihi. İstanbul: Divan Yayınları, 1983.

Sırma, İhsan Süreyya. Osmanlı Devleti’nin Yikılışında Yemen İsyanlar, İstanbul: y.y., 1982.

Sırma, İhsan Süreyya. Yemen'in Jeo-Politik Durumu ve Osmanlı Devleti'ne Katılması, İstanbul: Edebiyat Fakültesi Matbaas1, 1982.

Sūsuva, Abbas Ali. "Bākāya el-elfāz et-Turkiyye fill'-mahkiyyetill-Yemeniyye”. Mecelletu Mecma'i'l-Luğati'l-Arabiyye 2 (2013), 38-104.

Thomas, Justin. Psychological Well-Being in the Gulf States: The New Arabia Felix. London: Palgrave Macmillan, 2013.

Tkatsch, J. "Sebe”, İslam Ansiklopedisi. 10/273. İstanbul 1988.

Tomar, Cengiz. "Resûlîler", Türkiye Diyanet Vakfi İslam Ansiklopedisi. 35/1-2. İstanbul: TDV Yayınları, 2008.

Tomar, Cengiz. "Yemen'de Bir Türk Devleti: Resûlîler ve Âlim Sultanları". Osmanlı Araştırmaları Dergisi 33/33 (2009), 221-236.

Tomar, Cengiz. "Yemen", Türkiye Diyanet Vakfi İslâm Ansiklopedisi. 43/401-406. İstanbul: TDV Yayınları, 2013.

Ünal, Çağlar. Yemen Tarihi Hakkında Yazılmış Türkçe Eserler. Kastamonu: Kastamonu Üniversitesi Sosyal Bilimler Enstitüsü, Yüksek Lisans Tezi, 2018.

Üzüm, İlyas. "Zeydîler”, Türkiye Diyanet Vakfi İslâm Ansiklopedisi. 44/324-326. İstanbul: TDV Yayınları, 2013.

Watson, Janet. The phonology and morphology of Arabic. New York: Oxford University Press, 2002.

Winford, Donald. An introduction to contact linguistics. Oxford: Blackwell Publishing, 2003.

Yavuz, Hulusi. Yemen'de Osmanlı İdaresi ve Rumûzî Tarihi, Ankara: Yayınevi, 2003.

Yazıc1, Elif. Yemen Bölgesiyle İlişkili Kur'ân Kissalarının Tarihsel ve Kültürel Açıdan Tahlili. Adana: Çukurova Üniversitesi Sosyal Bilimler Enstitüsü, Doktora Tezi, 2019.

Yıldırım, Muhammet. XVI. Yüzyılda Osmanlı Devleti'nin Kızldeniz, Yemen, Basra Körfezi ve Habeşistan Politikalar. Isparta: Süleyman Demirel Üniversitesi Sosyal Bilimler Enstitüsü, Yüksek Lisans Tezi, 2001. 
Yıldız, Musa. "Türkçe ile Arapça Arasındaki Karşılıklı Etkileşim”. NÜSHA Şarkiyat Araşttrmalar Dergisi 23 (2006), 7-39.

Zebīdī, Ebu'l-Feyz Muhammed Murtazā. Tācu'l-'Arūs min Cevāhiri'l-kāmūs. thk. Abdülkerîm elAzbâvî. Kuveyt: Matbaatu Hukumetil-Kuveyt, 2001.

Zeydan, Corci. el-'Arab kable’l-İslām. Beyrut: Dāru Mektebeti'l-Hayāt, trs. 


\title{
TURKISH ELEMENTS IN YEMENI ARABIC
}

\begin{abstract}
Yemen, which is located on a number of important sea routes and has fertile lands, has been a place frequented by different cultures and civilizations, has hosted many states, and has always preserved its importance due to its geopolitics location. The Ottoman Empire was included in this region especially from the 16th century, and the Ottoman domination of Yemen continued until the beginning of the 20th century with interruptions. Despite many rebellions and troubles in the region during the time of the Ottoman Empire, political, administrative, religious and social structures were built, and Ottoman culture found a place of existence in Yemen, where different cultures lived together. One of these areas of existence is language, which is the interaction tool of cultures. In this study, it is aimed to determine the Turkish elements used in the Yemen Arabic dialect within the framework of Yemen-Ottoman relations and to evaluate them in various aspects. In fact, Turkish-Arabic interaction appears as a natural process that starts with the transmission of religious words as a result of the acceptance of Islam by Turks in general and makes its effects felt in other areas of life, up to the daily speech language. The language interaction between Turkish and Arabic was not one-sided, but both languages took words from each other and gave words. Although the official language used in state affairs in the Ottoman Empire is Ottoman Turkish, Turkish, Persian, Arabic, Greek, Armenian, etc. languages were also spoken. Thus, Ottoman Turkish has almost become an imperial language because it includes Arabic-Persian words and grammar rules. This situation has shaped the dimension of the influence of Turkish on Arabic dialects. In this respect, Ottoman Turkish has been the intermediary language in the transfer of Turkish words directly, Persian and many other western languages to Arabic dialects. Under the circumstances, the influence of Turkish in the Arab dialect of the Yemen region, both in terms of words and structures/suffixes, has been substantial and not underestimated compared to the dialects of other neighboring Arab countries (Syria, Iraq, Lebanon etc.). The influence of Turkish on the Yemen dialect has been observed in the daily spoken language as well as in the settlements-tribal names of the Yemen region and in the phrase expressions/proverbs.
\end{abstract}

Keywords: Yemen, Arabic, Turkish, lexicon, loanwords. 